\title{
Querns and mills during Roman times at the northern frontier of the Roman Empire (Belgium, northern France, southern Netherlands, western Germany): Unravelling geological and geographical provenances, a multidisciplinary research project
}

\author{
Sibrecht Reniere ${ }^{1}$, Roland Dreesen ${ }^{2}$, Gilles Fronteau ${ }^{3}$, Tatjana Gluhak ${ }^{4}$, Eric \\ Goemaere $^{2}$, Else Hartoch ${ }^{5}$, Paul Picavet ${ }^{6}$, Wim De Clercq ${ }^{1}$ \\ 1. Ghent University - Department of Archaeology - Faculty of Arts and Philosophy - Historical Archaeology \\ Research Group (HARG). Sint Pietersnieuwstraat 35, 900 Gent, Belgium. \\ Email: Reniere: sibrecht.reniere@ugent.be; de Clercq: w.declercq@ugent.be \\ 2. Royal Belgian Institute of Natural Sciences - Geological Survey of Belgium. Jennerstraat 13, 1000 Brussels, \\ Belgium. Email: Dreesen: roland.dreesen@telenet.be; Goemaere : egoemaere@naturalsciences.be \\ 3. University of Reims Champagne-Ardenne - Groupe d'Etude des Géomatériaux et Environnements Naturels, \\ Anthropiques et Archéologiques (EA 3795). 2, esplanade Roland Garros, 51100 Reims, France. \\ Email: gilles.fronteau@univ-reims.fr \\ 4. Johannes Gutenberg University Mainz - Institute for Geosciences - Team Geomaterials and Gemstone \\ Research. J.-J.-Becher-Weg 21, D-55128 Mainz, Germany. Email: gluhak@uni-mainz.de \\ 5. Gallo-Roman Museum, Tongeren. Kielenstraat 15, 3700 Tongeren, Belgium. Email: else.hartoch@limburg.be \\ 6. Lille University (Lille 3) - Laboratoire d'Histoire, Archéologie et Littérature des Mondes Anciens (HALMA \\ IPEL). Rue du Barreau, BP 60149 59653, Villeneuve d’Ascq., France. Email: paul.picavet@gmail.com
}

\begin{abstract}
:
This paper presents the results of a multi-disciplinary provenance study of querns and millstones during the Roman period $\left(1^{\text {st }}-4^{\text {th }}\right.$ century $\left.C E\right)$ in the northern part of the Roman Empire (provinces of Gallia Belgica and Germania Inferior). Comparative petrographical, mineralogical and geochemical analysis allowed an international team of archaeologists and geologists to identify the different raw materials used for the manufacturing of querns and millstones. As a result, lithostratigraphic assignments as well as geological-geographical provenances are suggested or corroborated for the broad spectrum of these natural geo-materials. We give evidence for the exploitation of at least seven different rock types. They include sedimentary rocks (fine- to coarse-grained quartzitic and arkosic sandstones, conglomerates, limestones) and volcanic rocks (vesicular lavas) derived from different geological strata in the following geological-geographical settings: the volcanic Eifel area (Pleistocene lava), the Ardennes Massif (Palaeozoic sedimentary rocks) and the Paris and Northern Sea Basin (Cenozoic sedimentary rocks). Furthermore we show that a large diversity existed within different productions (different types of hand-mills and mechanical powered mills) and distribution patterns. This paper provides new data which will lead to fresh insights into the socio-economics of the local "Gallo-Roman" communities and into their networks within the northern Roman Empire.
\end{abstract}

Published by the School of History, Classics and Archaeology, University of Edinburgh ISSN: 2055-0472. URL: http://journals.ed.ac.uk/lithicstudies/

This work is licensed under a Creative Commons Attribution 2.5 UK: Scotland License. 
Keywords: geoarchaeology; provenance study; millstone; querns; ground stone tools; Roman Empire; Gallia Belgica; Germania Inferior

\section{Introduction}

This paper presents the preliminary results of both ongoing and finished research projects and highlights the importance of an international and interdisciplinary collaboration between archaeologists and geologists, when it comes to raw material studies. Whereas local studies stop at the frontier, this international cooperation allows us to cross present borders to conduct a more holistic analysis of ancient stone distribution networks. It focuses on the provenance study of querns and millstones during the Roman period $\left(1^{\text {st }}-4^{\text {th }}\right.$ century CE) in the provinces of Gallia Belgica and Germania Inferior.

The aim of the research is to characterize the geo-materials, to map the different geological and geographical provenance regions and if possible to identify potential millstone quarry-sites. The studied provinces are located between the rivers Seine and Rhine, in the northernmost parts of the Roman Empire, and were administratively subdivided into civitates or districts in Antiquity. They are now situated in northern France, western Germany, southern Netherlands and Belgium. One research project studies the entire region whereas two other projects focus on Belgian micro-regions: the province of Limburg in the east (being part of the Civitas Tungrorum with Tongeren as the caput civitatis) and the Civitas Menapiorum in the northwest. The Civitas Tungrorum is situated in the province of Germania Inferior and is now part of southern Netherlands, the Belgian province of Limburg (where the capital Tongeren or Atuatuca Tungrorum is located) and a large part of southeast Belgium. The Civitas Menapiorum was part of Gallia Belgica and is now covered by the current Belgian provinces of East- and West-Flanders, the Dutch province of Zeeland and the northern part of the department Nord-Pas-de-Calais (France) (Figure 1).

Rotary querns and mills were common in domestic Roman contexts, including rural settlements, urban sites and military camps. These tools were used for grinding many products and were of vital importance at a daily subsistence level. They mainly ground cereals, which were an essential part of the diet in pre-Roman and Roman societies. We usually differentiate the upper rotating stone, the catillus, and the lower fixed stone, the meta. The hand-driven querns (diameter smaller than $50 \mathrm{~cm}$ ) were used on the household level, whereas millstones (diameter larger than $50 \mathrm{~cm}$ ) were deployed on a larger scale. Provenancing the geo-materials that were used to manufacture these tools can reveal commercial networks, as these grinding tools are excellent markers for transport roads, inferring socio-economic exchange paths.

The study region has been restricted to four major geological megastructures: the Paris Basin, the Northern Sea Basin, the Ardenno-Rhenan Massif and the Volcanic Eifel Field. The geological nature of the study region obviously plays an important role in the supply and distribution networks of geo-materials and their finished products. This is particularly interesting for stone artefacts found in stone-poor landscapes such as those of northern Belgium and the Netherlands. It implies that stone had to be imported from outside the region. Furthermore other natural constraints such as relief and hydrography played a role in the distribution patterns. Besides these natural elements, human and technological factors played a role in the choice of raw materials. Driven by technical necessities (workability and efficiency of the rock) and practical requirements (availability and distance of the source) specific stone types have been selected (Fronteau \& Boyer 2011).

The research projects investigate provenance and distribution networks, and attempt to define stone tools within technological, typological and chronological frameworks. All these 
aspects will provide further insights into the socio-economics of the local "Gallo-Roman" communities and into their networks within the northern Roman Empire.

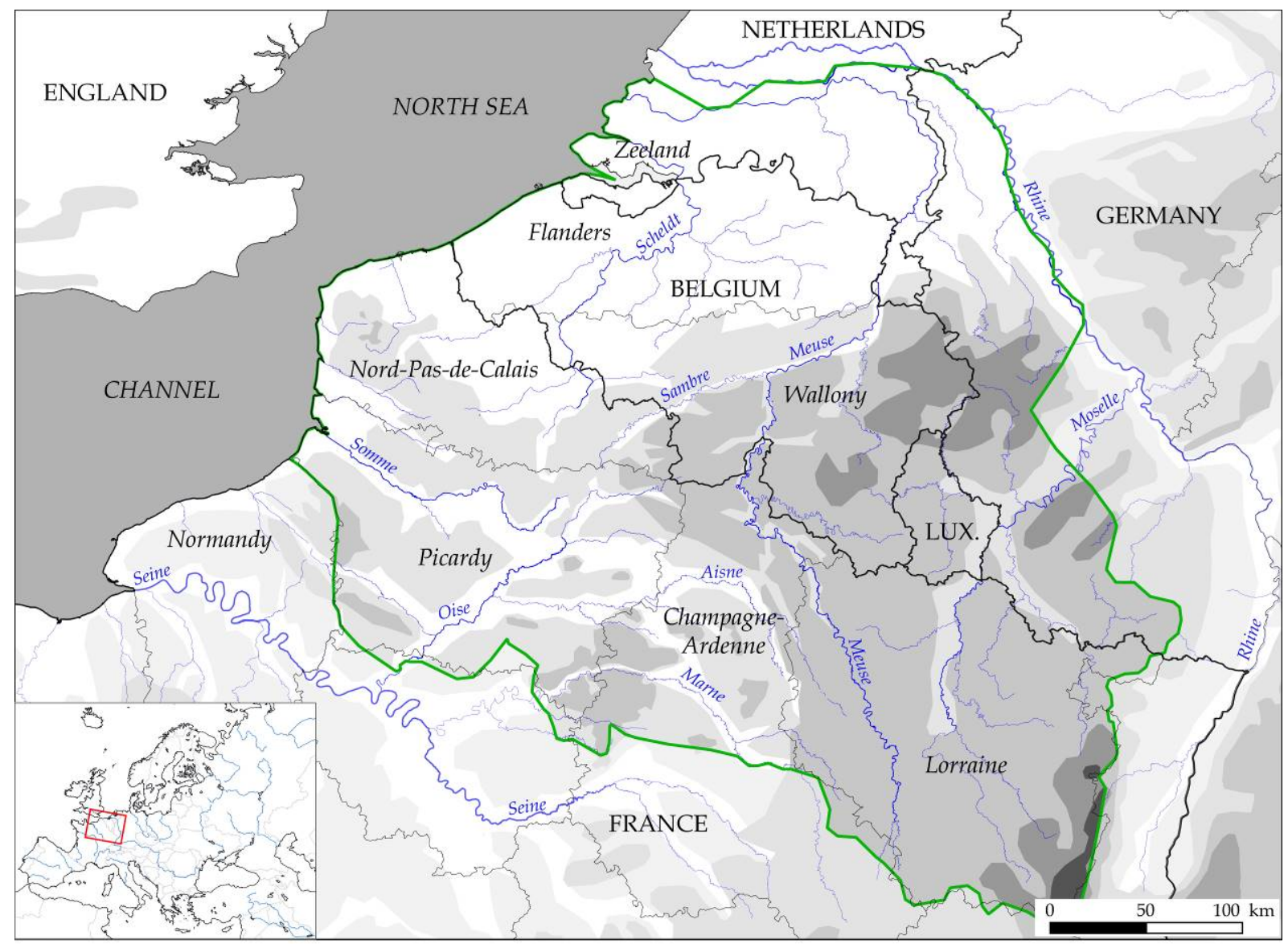

Limits of the roman Provinces of Gallia Belgica and Germania Inferior (after Deru 2010)

Altitude: $\square 1000 \mathrm{~m} \square 500 \mathrm{~m} \square 200 \mathrm{~m} \quad \square 100 \mathrm{~m}$

Figure 1. Localisation of the study region (after Deru 2010).

Although querns and millstones are common in archaeological sites, until recently the (provenance) study of Roman stone tools has been given little attention amongst scholars in the study region. Research was often of local interest and had a very regional character linked with known resource areas (for example important studies of the protohistoric saddle and rotary querns of the Aisne valley, France (Pommepuy 1999)). Nevertheless, some preliminary work has been done in the past. For northwestern Belgium we can mention the petrographic studies done by De Paepe between 1965 \& 1988. This resulted in several publications, in excavation reports and one general paper (De Paepe 1965a; De Paepe 1965b; De Paepe 1972; De Paepe 1976a; De Paepe 1976b; De Paepe \& Vermeulen 1988).

Exhaustive publications on provenance analyses of these grinding tools are rare. In excavation reports, lithic artefacts are often determined without consultation of a geologist and therefore often lack detailed or accurate stone determinations and source determinations. Archaeologists and geologists are now more frequently collaborating when it comes to unravelling the geological nature and geographical provenance. Because of long-distance exchanges of these geo-materials (crossing modern borders), the set-up of international networks of specialists is required. A good example of such collaboration is the French research group Groupe Meule (Programme Collectif de Recherche: "Évolution typologique et technologique des meules du Néolithique à l'an Mille sur le territoire français” in short 
"Groupe Meule") (results first published in Buchsenschutz et al. 2011 and more recently presented in Reims, France in May 2014 and to be published in the Revue Archéologique de l'Est). Two other examples are the recent paper published in the European Geologist magazine, dealing with geological and geographical provenances of lithic materials during Roman times in Belgium (Dreesen et al. 2014) and the recent published book "Moudre au Pays des Tungri” (Hartoch et al. 2015).

\section{Methodology}

The determination of raw geo-materials is based on classical techniques of investigation. The identification of lithology is made through macro- and mesoscopic observations. A comparative petrographic analysis of thin sections is used to fine-tune on a microscopic level: it has been performed on sedimentary and volcanic rock specimens taken from geological samples and archaeological findings.

For the "basalt"-type lava rocks, geochemical-statistical analysis complements the petrographic study. The analysis consists of Wavelength-dispersive X-ray Fluorescence (WDXRF) used to measure the major elements and trace elements. These analyses were followed by an evaluation of the data in an appropriate geochemical discrimination diagram (e.g., total alkali silica (TAS)-diagram for volcanic rocks) to decide if a provenance from the Eifel volcanic field can be taken into account or has to be rejected. The allocation of the samples to the Eifel region and furthermore to a certain quarry in the Eifel is done by statistical cluster and discriminant analysis. For a more detailed description of the methodology we refer to Gluhak \& Hofmeister (2009; 2011).

Finally lithostratigraphic ages, geological and geographical provenances can be proposed. In the context of this paper, we want to stress that the setup of databases (e.g., Groupe Meule), the development of reference collections of raw materials and thin sections, and the cross-border exchange of data and rock specimens are essential to fill the numerous gaps in our knowledge (Dreesen et al. 2014).

Although it is not the aim of this paper to study the distribution patterns and the diversity of each production in detail we present some general patterns. As they are based on ongoing research it is not possible to present an exhaustive quantified dataset. Where possible we will refer to published datasets of some micro-regions (e.g., Gluhak \& Hofmeister 2011; Hartoch et al. 2015; Picavet in press b).

\section{Results: the main geo-materials used in the studied area}

As a result of our multidisciplinary research, different lithostratigraphical assignments as well as geological-geographical provenances have been suggested for the identified geomaterials (Figures 2 and 3).Three major rock-groups can be distinguished: volcanic rocks (extrusive igneous rocks), detrital sedimentary rocks and (bioclastic) limestones. The volcanic rocks consist of one main rock type, described as "basalt"-like lava. The detrital sedimentary rocks consist of six different rock types: dark red Devonian conglomerates, light-coloured Eodevonian coarse sandstones and conglomerates ("Macquenoise"), light-coloured Devonian arkosic coarse sandstones and conglomerates, Tertiary quartzarenites (sandstones with $>95 \%$ of quartz), French Tertiary puddingstones and 'Fosse-Belleu' Ypresian sandstones. Limestones consist of different fossiliferous facies of Lutetian limestones from the northern part of the Paris Basin. For each rock type we describe the lithology followed by a litho- and chrono-stratigraphic assignment. If possible, known quarry sites and potential quarry sites are suggested. Finally general information on chronology, typology and distribution is suggested. 


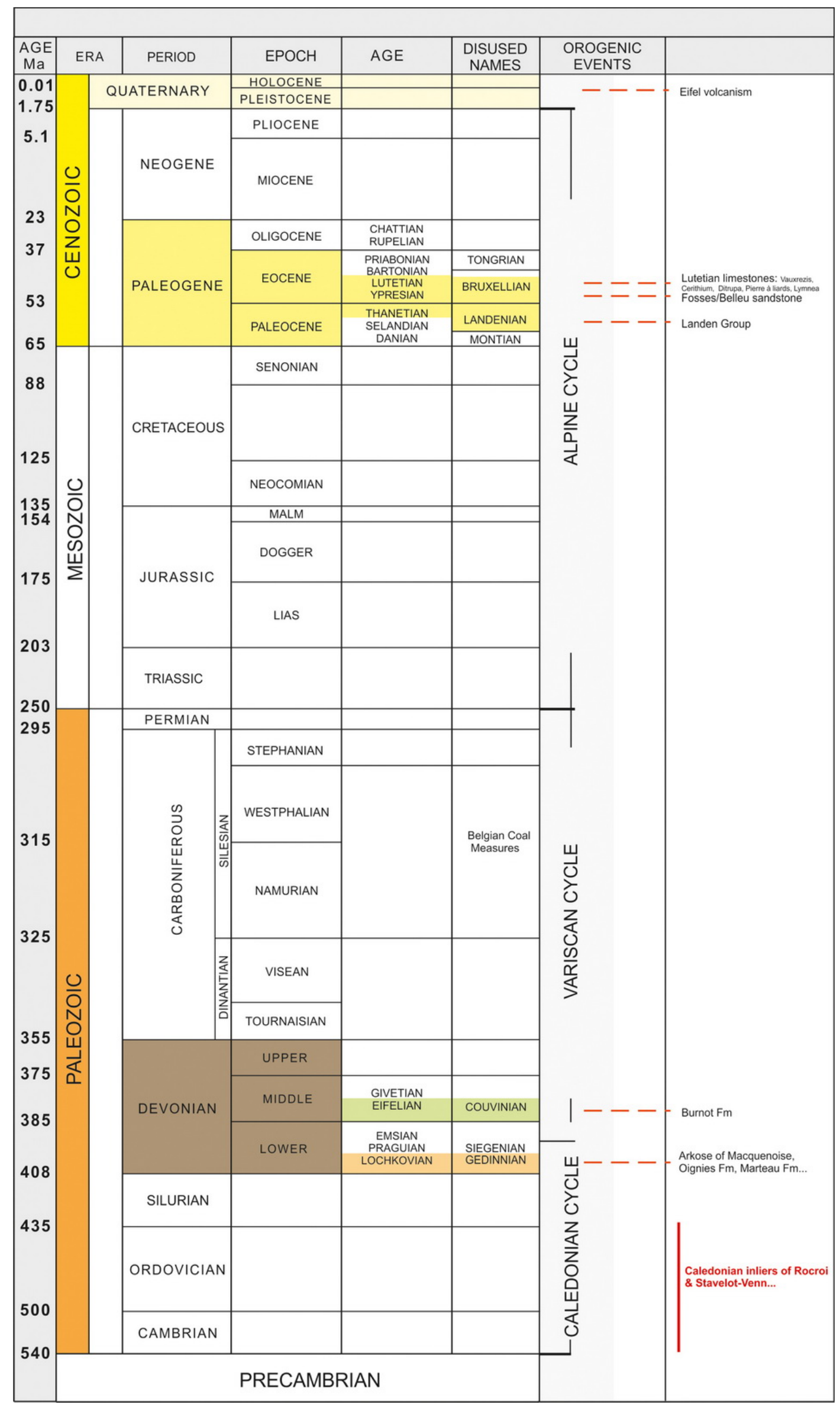

Figure 2. Geological timescale with the stratigraphic assignments of the mentioned geo-materials. 


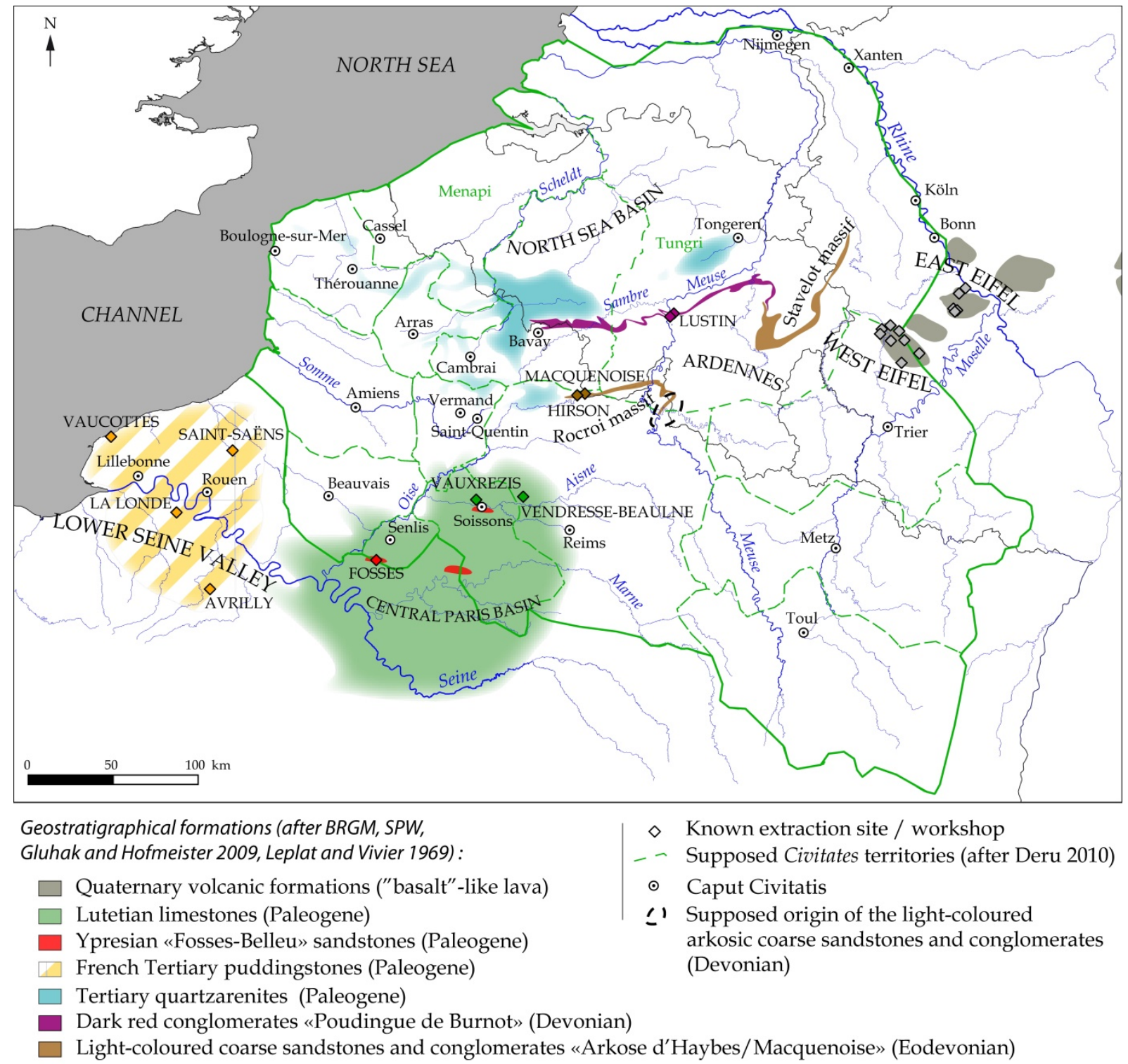

Figure 3. Localisation of the geological-geographical provenances.

\subsection{Volcanic rock: “basalt"-like lava}

The "basalt"-like lava is a fine-grained, grey, vesicular rock with vesicles up to a few millimetres in size and common felsic xenolith inclusions. On the fresh surface small clinopyroxene phenocrysts as well as occasional larger (up to $10 \mathrm{~mm}$ ) sanidine phenocrysts can be observed. According to its modal mineral content the lava can petrographically be defined as a tephritic phonolite (not as a true basalt). The fine-grained matrix is mainly composed of nepheline, sanidine, clinopyroxene crystals, plagioclase and opaque ores with minor grains of leucite and apatite. Querns and millstones in this lava are often poorly conserved, especially on the acid sandy soils of the Civitas Menapiorum. In these cases the surface is weathered and strongly corroded. The alteration can be related to acidic depositional contexts and the nature of the rock itself: the vesicular texture and the alterability of plagioclase and ferromagnesian minerals. Examples that were found under the permanent water table are generally in better condition (Reniere et al. in press) (Figure 4). 


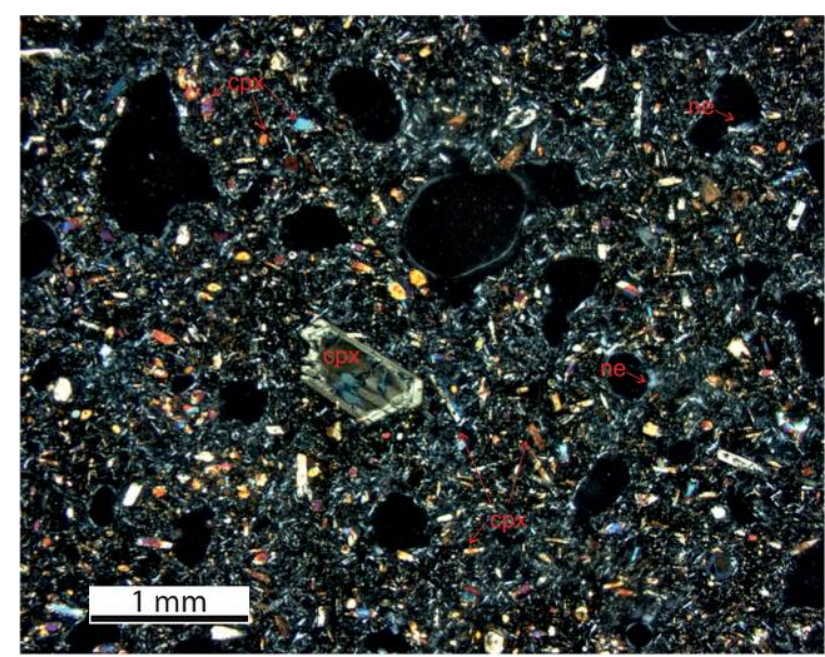

a
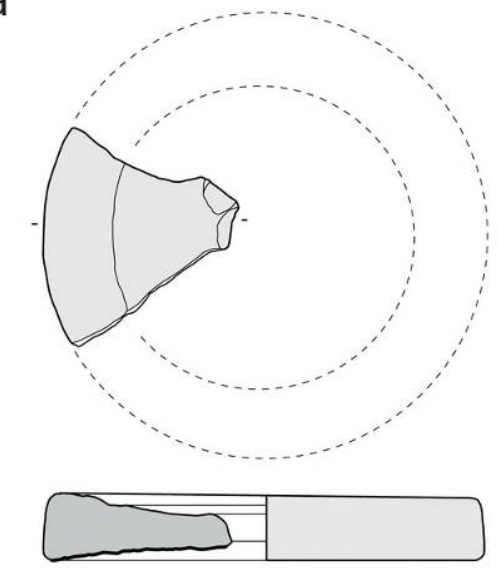

C

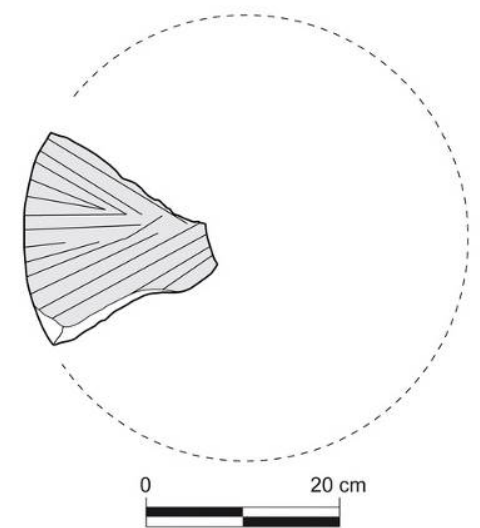

d

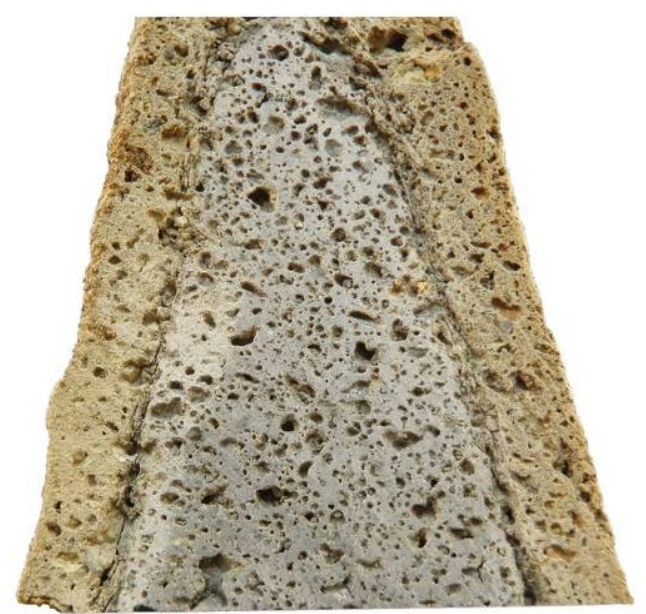

$\mathrm{b}$

$15 \mathrm{~cm}$

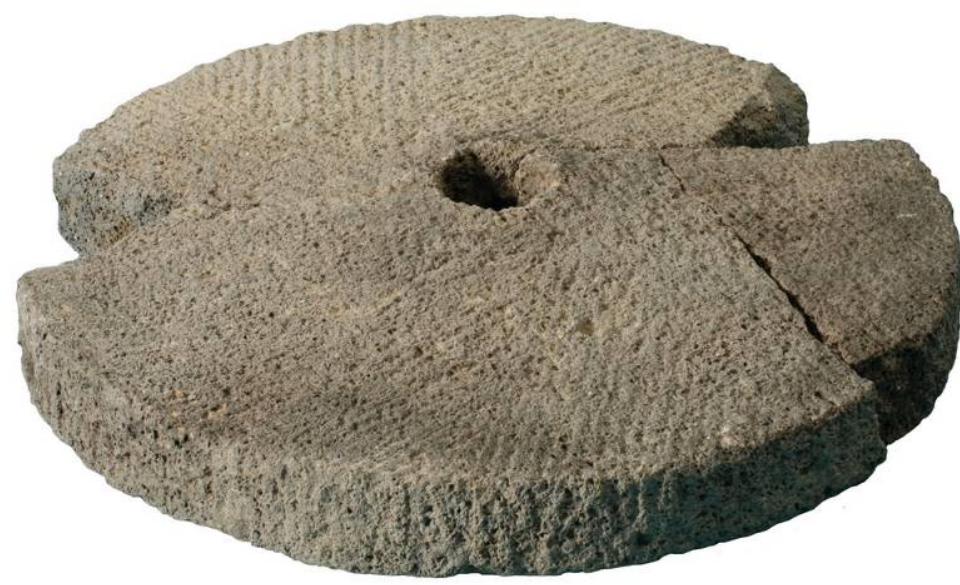

0

$15 \mathrm{~cm}$

Figure 4. Volcanic rock, "basalt"-like lava. a) Micrograph of thin section: tephritic phonolite with nepheline (ne), sanidine, clinopyroxene (срx) crystals and opaque ores with minor grains of leucite and apatite. Transmitted light with cross polarization (Hartoch et al. 2015, fig. 32), b) Macroscopic detail: illustration of the weathered outer crust (left and right) and the typical vesicles c) Figure of a catillus from Wijnegem-Belgium., d) Meta from Oudenburg Spegelaere-Belgium.

These tephritic phonolite lavas were imported from the Vulkaneifel in Germany (the procedure of the provenance analyses as well as the necessary data from the extraction sites are given in Gluhak \& Hofmeister (2009; 2011)). This region consists of three volcanic fields. The first one, the Hocheifel, is of Tertiary age, while the other two, the East Eifel and the West Eifel, are of Quaternary age. Volcanic rocks were mined from pre-Roman times until modern times (20 ${ }^{\text {th }}$ century) (Mangartz 2008). Besides the German Vulkaneifel, we should note some other regions (without being exhaustive) where volcanic rocks were exploited, 
such as the Massif Central in France, Agde (Languedoc-Roussillon, France), Vogelsberg (Land of Hesse, Germany), some regions in Italy (Orvieto in Umbria, Vulture in Basilicata, Sardinia, Sicily etc.) and the Pannonian Basin (East-central Europe) (Peacock 1980; Mangartz 2008: 195-207; Gluhak \& Hofmeister 2011).

In older literature the Eifel region was frequently proposed as a source for millstones in Roman and Medieval times in the region, often based only on macroscopic and petrographic observations (Kars 1980; De Paepe \& Vermeulen 1988). Archaeometrical research on Roman millstones is mainly confined to the Mediterranean (we cite some examples after Gluhak \& Hofmeister (2009) without being exhaustive: e.g., Peacock 1980; Williams-Thorpe \& Thorpe 1993; Antonelli et al. 2001, Renzulli et al. 2002; Buffone et al. 2003). Thanks to the recent detailed analytical geochemical-statistical methodology developed by Gluhak (2010) it is possible to link Roman querns and millstones made of volcanic rocks to particular extraction sites, even to an individual quarry or lava flow. This analysis enables researchers to link querns and millstones to extraction sites in the Eastern Eifel area. The quarries of the Bellerberg volcano in Mayen form the most important production site of the region during the Roman period, both for hand-mills, water mills and animal-geared mills (Mangartz 2008: 52106).

A production of hourglass-shaped Pompeian-style millstones is also known (Gluhak \& Hofmeister 2011; Jaccottey \& Longepierre 2011; Hartoch et al. 2015: 32-34). The quarries were exploited very intensively and their products had a very wide distribution. A provenance analysis on 62 millstones found in France, Germany and Austria found that all identified Eifel millstones could be attributed to the Bellerberg volcano. Twenty-six of them were extracted in the Mayener Grubenfeld quarry, followed by 14 millstones from the Kottenheimer Winfeld quarry. Few millstones (4) were made from Ettringer Lay lava (Gluhak \& Hofmeister 2011). The recent study of "basalt"-like lava querns and millstones from the province of Limburg (Belgium) showed that they were also mainly exported from the same two dominating quarries (Hartoch et al. 2015: 51-61).

A petrographical and geochemical analysis for the "basalt"-like lava millstones from the Civitas Menapiorum is in progress. Although further research on the distribution network and export region of the Eifel millstones is necessary, recent studies revealed that querns and mills in "basalt"-like lava were in great demand and had a very large 'export territory' especially compared with other raw materials (Gluhak \& Hofmeister 2011; Hartoch et al. 2015: 79-86; Picavet in press b). At this moment the extreme southern exports in France are known in Mirebau (Departement of Poitou-Charentes, France) and Offement (Departement of FrancheComté, East France). The extreme southeastern Eifel products are registered in Kempten (Bavaria, South Germany) and Magdalensberg (Carinthia, South Austria) while the northern and northwestern exports are less documented (Gluhak \& Hofmeister 2011).

\subsection{Detrital sedimentary rocks}

\subsubsection{Dark red Devonian conglomerates}

These conglomeratic rocks are poorly sorted and composed of millimetrical- to pluricentrimetrical-sized well-rounded clasts (granules and pebbles) in a dark-red (called "lie de vin") terrigenous matrix made of quartz, lithic fragments and clay minerals. The clasts consist of grey, green and reddish sandstone and quartzite pebbles (generally varying between $4 \mathrm{~mm}$ and $60 \mathrm{~mm}$ ), white pebbles derived from vein quartz, and dark green and black small pebbles composed of tourmalinite (rock that mostly consist of minute crystals of tourmaline and quartz). Tourmalinite granules and pebbles are very characteristic of this material. The conglomerates are further characterized by garish hues. Red colors dominate whereas the grey variants (grey and light grey) are less represented. Important accessory minerals are dark 
green and black plurimillimetrical (or fragments of) tourmaline crystals occurring within the siliciclastic matrix. Quartzitic textures are locally developed, as well as overgrowth textures underlined by red clay fringes. Micrograins of iron oxide can be locally observed. Quartzite pebbles show evidence of pressure-solution: stress was concentrated at contact points between pebbles (or cobbles): this locally triggered the dissolution of the quartz, which was reprecipitated as quartz veins. Millstones are made in a broad spectrum of materials, ranging from coarse red conglomerates to fine- to medium-sized red sandstones with isolated granules of quartz or quartzite (Figure 5).

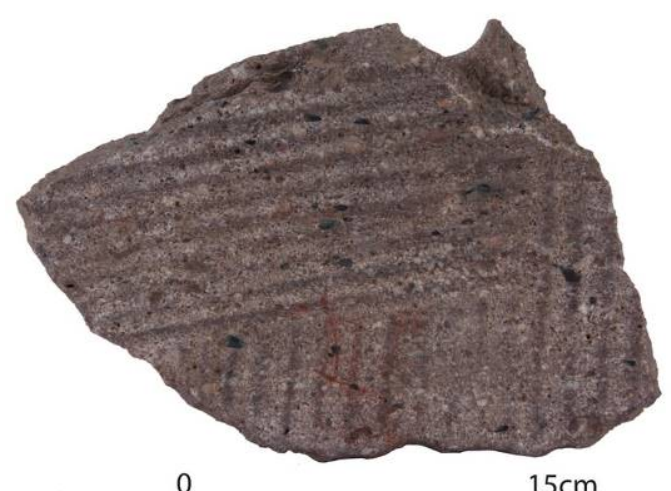

a

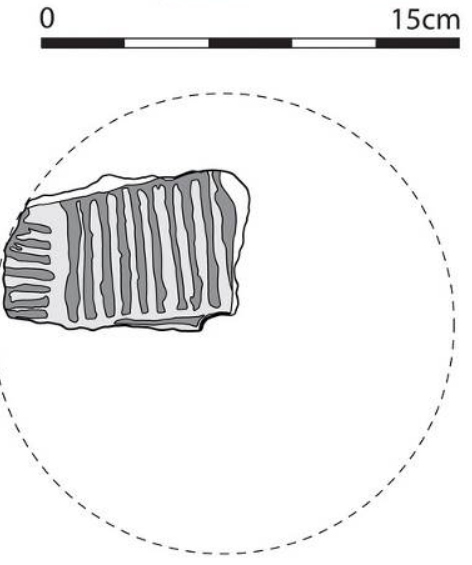

$\mathrm{b}$
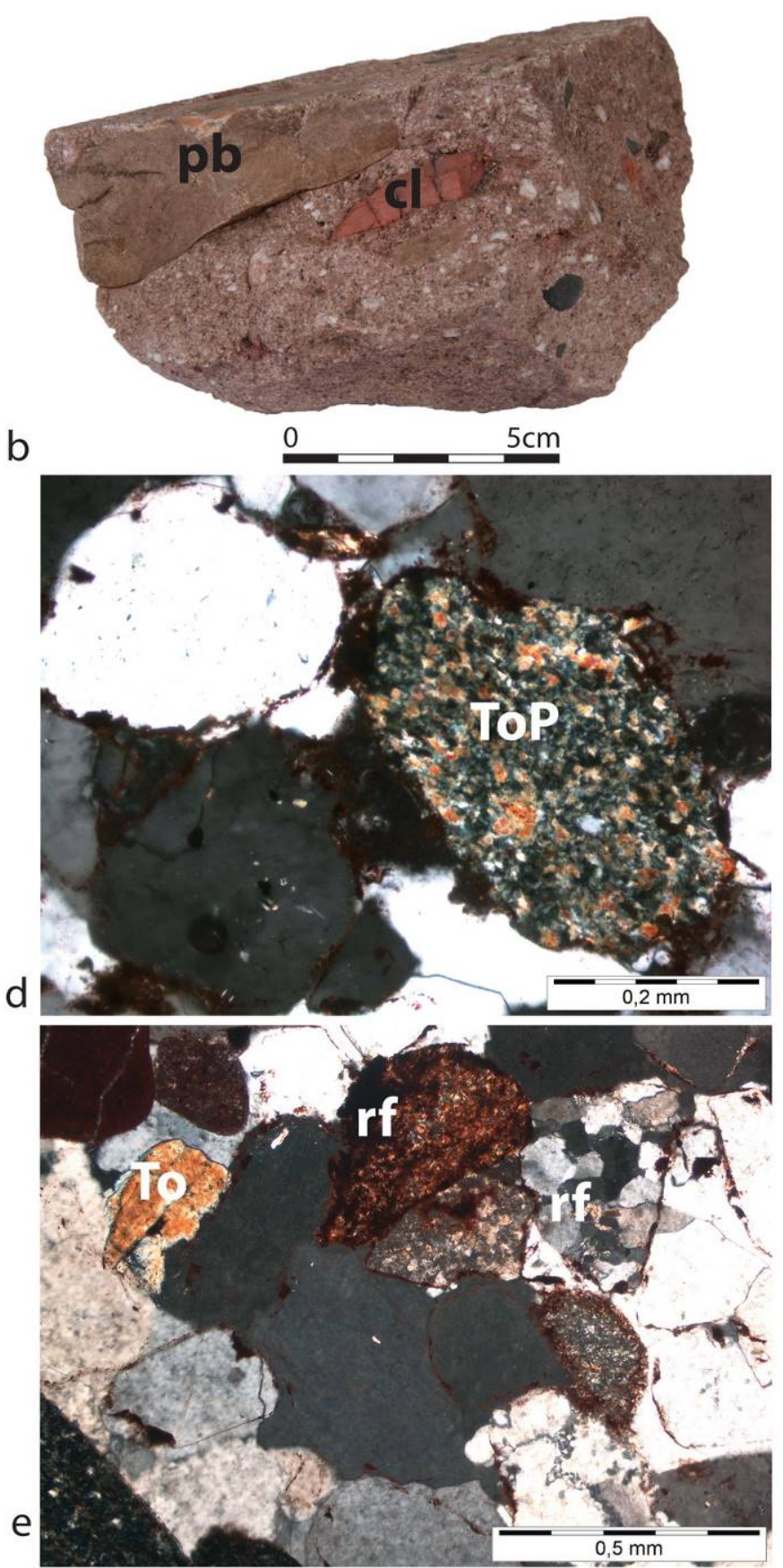

C

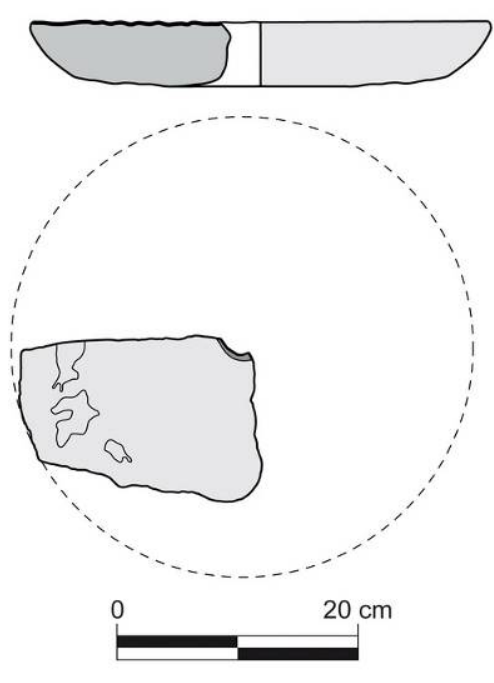

Figure 5. Dark red Devonian conglomerate. a) Meta from Zele Kouterbos-Belgium, b) Macroscopic detail: pebbles (pb) and clasts (cl) in a dark-red matrix made of quartz, lithic fragments and clay minerals. Quite characteristic are the dark tourmalinite (ToP) pebbles, c) Figure of a meta from Zele Kouterbos-Belgium, d-e) Micrograph of thin section: quartz grains with quartzitic and overgrowth textures, rock (rf) fragments (e.g., tourmalinite (ToP) figure d and tourmaline grain (To) figure e). Transmitted light with cross polarization. 
All these rocks are of Lower Devonian (Marteau Formation, Lochkovian, Lower Devonian) or more probably of Middle Devonian age (Burnot Formation, Middle Eifelian). In the old literature and in the Belgian geological maps (prior to 2000), they were often referred to as "Poudingue de Burnot" (Stainier 1994). Source areas are known along the northern border of the Dinant Synclinorium and within the Verviers Synclinorium, in the northern part of the Walloon region (Belgium). The quarry sites are potentially numerous as this type of rock crops out in the Sambre, Meuse and Vesdre valleys and their tributaries. Only one potential quarry site or quern workshop is known in the region of Lustin at present. Here, outcrops are known and several semi-finished querns have been found (Cattelain et al. 20122013: 60; Picavet in press b). The production consists mainly of small hand-mills (diameter 31-40 cm, Figure 5). Their distribution was quite restricted with an approximate range of 100 $\mathrm{km}$ around the outcrops.

\subsubsection{Light-coloured Eodevonian coarse sandstones and conglomerates.}

This rock is a (micro-)conglomerate (representing a variety of "conglomerates, muddy sandy conglomerates, sandy conglomerates and pebbly muddy sandstones” sensu Folk's classification) (Folk 1954: 346-351; 1974: 25-27) composed of poorly-sorted, rounded or subangular rock fragments (quartzites, quartz, phyllites) cemented by quartz and recrystallized clay minerals (sericite). Feldspar grains are rare. The rock is characterized by light grey colours with yellowish and rose shades (weathering colors). Abundant dark green and black coloured plurimillimetrical-sized tourmaline grains and crystals are typical as well as the mica flakes (muscovite). Both are clearly visible at macroscopic level. Another typical aspect in some facies is the pronounced schistosity or schistose foliation that bypasses the pebbles. Mica grains undergoing solution transfer are aligned in this preferential orientation. These features are the result of a compressive tectonic phase linked to the Variscan tectonic cycle (see for example Boulvain \& Pingot 2015: 90-109) for a recent synthesis of the Walloon geology). The presence of quartz veins can result in a less homogeneous character of the stone and can affect the durability and the general shape of the millstones (Figure 6).

Due to the presence of numerous white spots (presumably newly formed kaolinite after feldspar weathering), these types of rocks were first described as "Arkose d'Haybes, Arkose de Macquenoise, Arkose de Waimes or Arkose de Vielsalm", which refers to the eponym location of the stratigraphic formation and to their different facies. It should be stressed here that these rocks are not real arkoses because, from a lithological point of view, a real arkose is a sandstone containing at least 25\% feldspars (according to Folk’s (1954: 354; 1974: 123127) classification and Pettijohn's (1975: 214-216)).

The rocks are Lochkovian in age (Lower Devonian). Two major source areas are known in the Ardennes Massif (Belgium), more especially around the Caledonian inliers, the Rocroi Massif and the Stavelot-Venn Massif. Around the Rocroi Massif they crop out from the region of Mondrepuis, Hirson and Macquenoise (Department of the Aisne-France, Province of Hainaut-Belgium) through the region of Haybes and Gedinne (Department of the Ardenne, France and in the Province of Namur-Belgium). Around the Stavelot-Venn Massif they are present from Baraque de Fraiture onwards until Recht and Waimes (Province of Liège and Province of Luxembourg). In both inliers two large quarrying 'districts' have been identified (the area of Hirson and Macquenoise and the area of Salmchâteau and Recht) through the presence of a marked landscape in relation with the presence of semi-finished querns and millstones (the area of Hirson and Macquenoise and the area of Salmchâteau and Recht) (Picavet 2011). Local inhabitants, erudite residents and historians have drawn attention to the existence of old quarries from the $19^{\text {th }}$ and $20^{\text {th }}$ century onwards. Picavet recently published a status quaestionis of the historiography of these sites (Picavet 2011; Picavet et al. in press). 
Roman exploitation is actually only known from the district of Hirson and Macquenoise. Hand-mills as well as larger mechanical geared millstones were produced and had a distribution radius of 100 to $200 \mathrm{~km}$. In the district of Salmchâteau and Recht there is currently only proof for proto-historical, medieval and modern exploitation. Nevertheless, the existence of Roman quarrying in this region cannot be excluded as the later extractions might have obliterated the older ones.

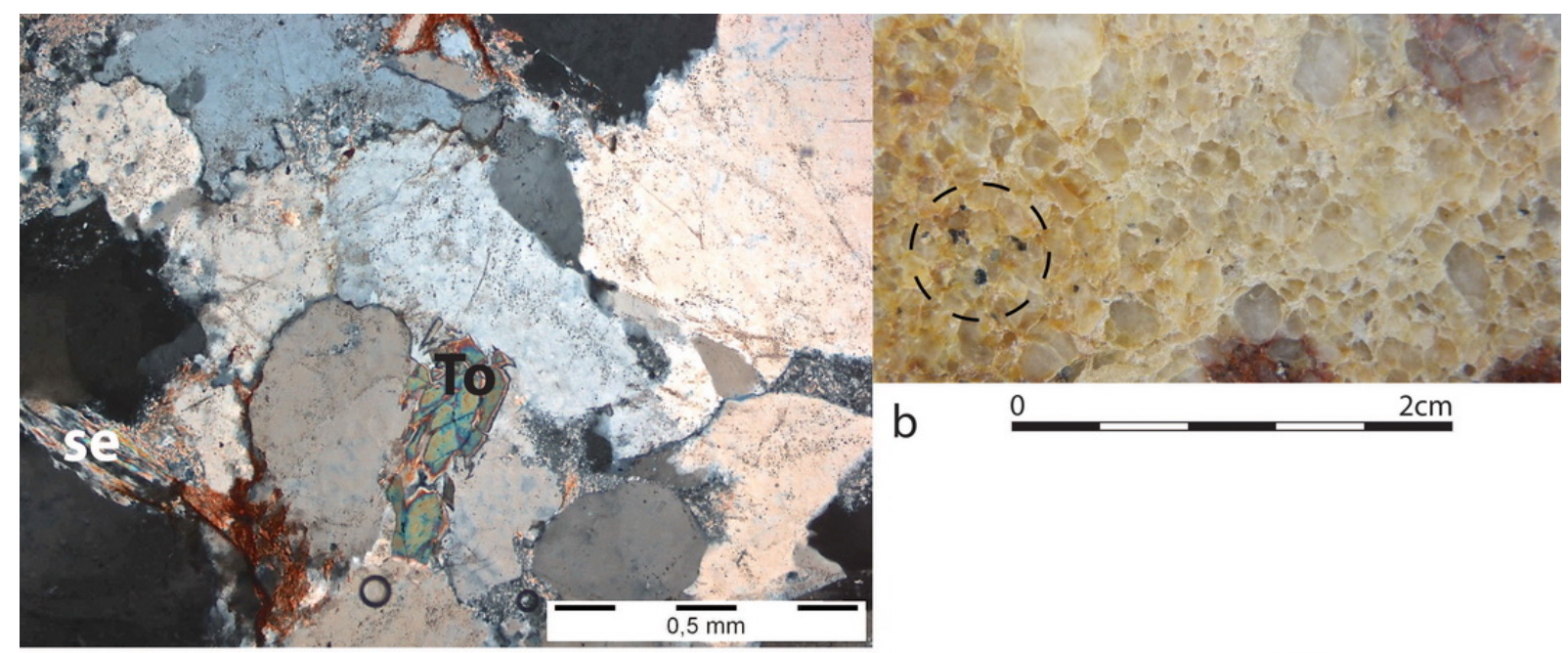

a
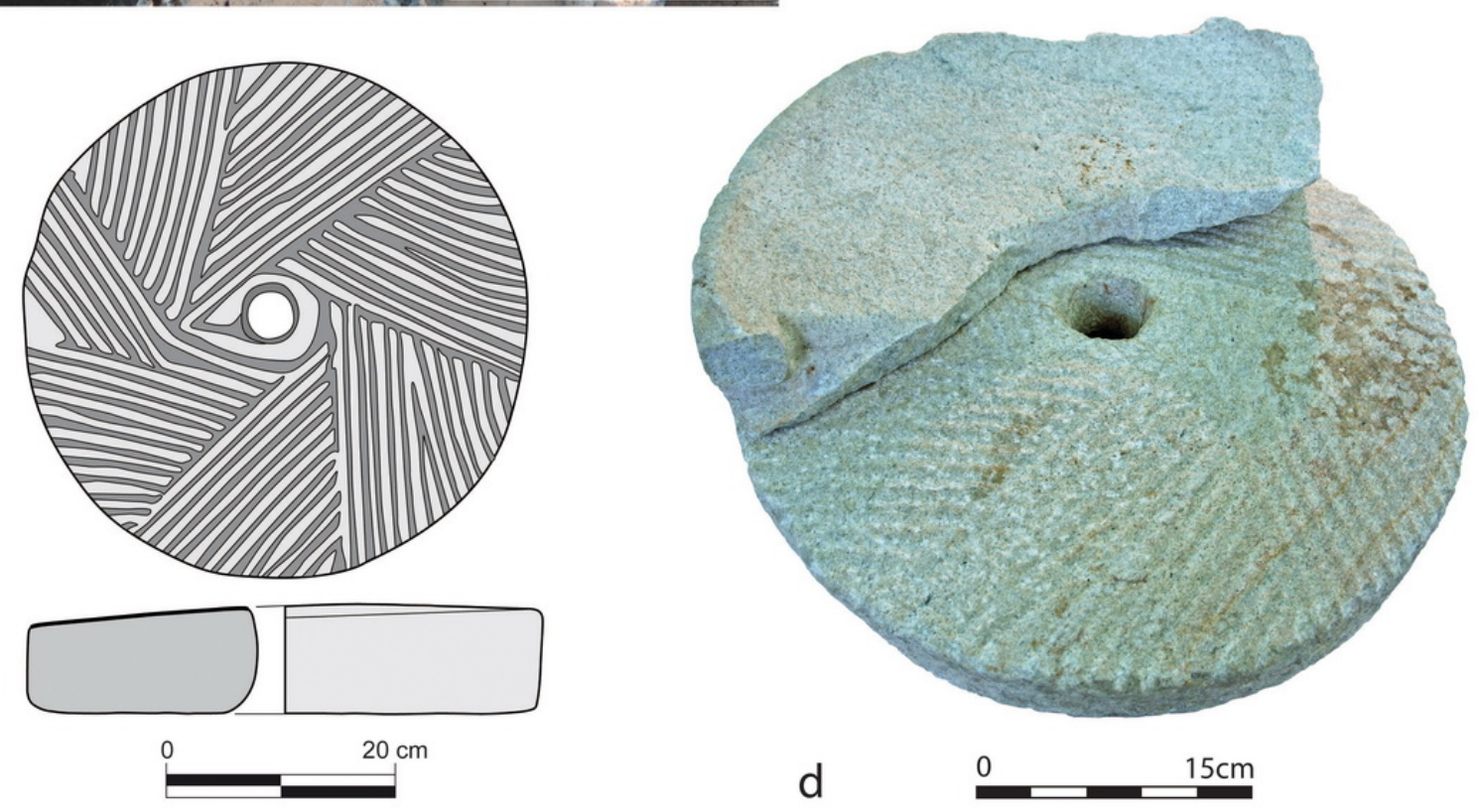

Figure 6. Light-coloured Eodevonian coarse-grained sandstone and conglomerate a) Micrograph of thin section: quartz grains, fragmented tourmaline grain (To) and recrystallized clay minerals (sericite - se). Transmitted light with cross polarization, b) Macroscopic detail: quartz grains cemented by recrystallized clay minerals, dark green tourmaline grains (see inside the black circle), yellowish and red shades as a result of weathering, c) Meta from Marquion-France , d) Catillus and meta from Marquion-France.

\subsubsection{Light-coloured Devonian arkosic coarse sandstones and conglomerates}

These rocks are poorly sorted coarse-grained (microconglomeratic) arkosic sandstones ("subarkose” according to Folk's (1974) classification) with quartz granules and pebbles (the latter conglomeratic sandstones include a broad spectrum of varying rock types that can be classified as muddy sandy conglomerates, sandy conglomerates and pebbly muddy sandstones according to Folk's classification). Rock colours vary from grey with salmon pink hues to pink and pale red. The colour of the quartz ranges from grey, milky-white to translucent. The 
stone contains numerous feldspars crystals (essentially orthoclase and microcline) that are often partially or strongly kaolinized (producing a white to yellowish powder). This weathering leads to a secondary porosity. Yellow and pink colours are due to the weathering of iron sulfides. Depending on the proportion of feldspars the rocks are either true arkoses or arkosic sandstones. Furthermore different milli- to centrimetrical-sized lithoclasts of sandstones, siltstones, shales, (micro-)quartzites and igneous rock fragments occur. Some mica flakes can also be seen (Figure 7). For a more exhaustive description we refer to the recent descriptions by Goemaere in Hartoch et al. (2015: 62-71).

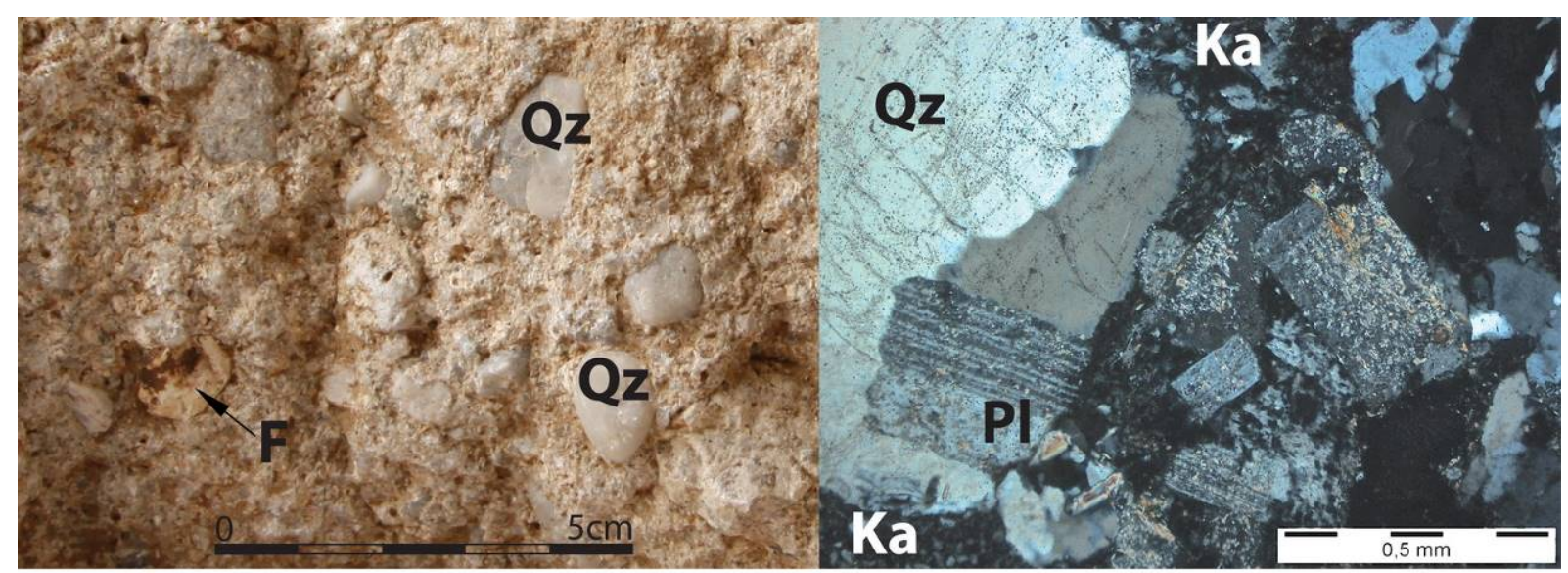

a

b
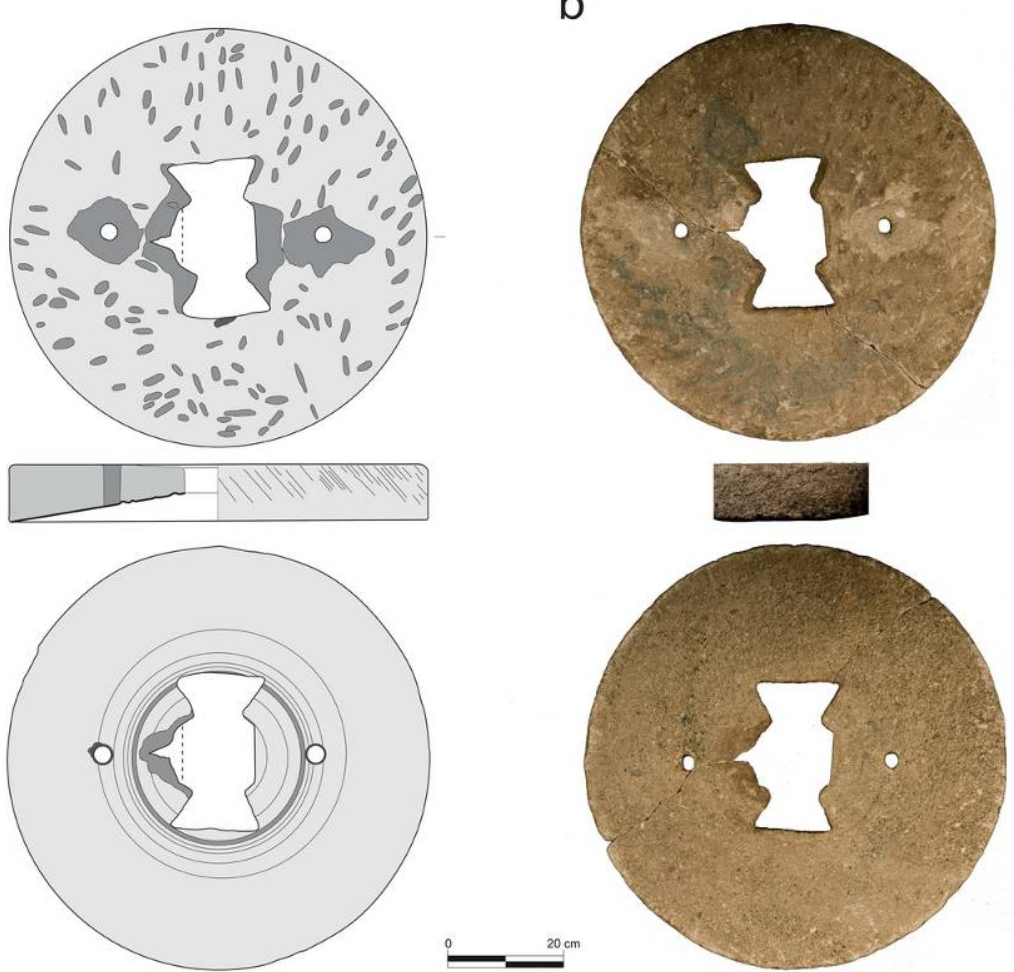

C
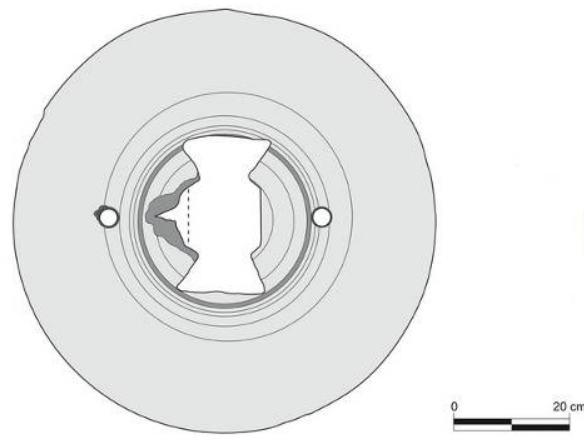

Figure 7. Light-coloured Devonian arkosic coarse sandstone and conglomerate ("subarkose" according to Folk's sandstone classification). a) Macroscopic detail: quartz granules and pebbles. One pinkish feldspar grain (F). White colour resulting from the kaolinization of feldspar crystals, b) Micrograph of thin section: example of feldspars (K-feldspar and plagioclases - Pl) weathering producing kaolinite crystals (Ka). Transmitted light with cross polarization, c) Catillus from Herk-de-Stad - Belgium (Hartoch et al. 2015: fig. 155).

The rock is of Lochkovian age (Lower Devonian) and is assigned to the lower third of the Oignies Formation. Deposits are known at the south and the southeast of the Rocroi Massif through the region of Transinne (province of Luxemburg, Belgium). Geologically, the 
feldspars could be linked to magmatic activity affecting the Rocroi Massif and could be contemporary with the series of Eodevonian sedimentary deposits. Nevertheless, these minerals still have to be studied. Quarry sites have not been identified at present. However, the geological and geographical origin of certain millstones still cannot be determined. The rock source of millstones made of light coloured microconglomerates with (pluri-)centrimetrical, subautomorph and unaltered feldspars is still undetermined.

From a technological and typological point of view, the arkosic sandstone seems to be (although not exclusively) linked with millstones with a large diameter (exceeding 50-60 cm diameter) (Hartoch et al. 2015: 240-248; Picavet in press a), which means that they were mainly mechanical driven (water or animal power). Millstones in this type of rock had a very large distribution and examples are known in the entire study region.

\subsubsection{Tertiary quartzarenites}

These are fine to medium or coarse-grained silicified sandstones with a colour ranging from light grey to cream to whitish, sometimes displaying red and rose shades. Rounded quartz grains are cemented by one or two generations of silica, resulting in sub-conchoidal fractures and a saccharoid texture. Macroscopically, they are quite similar to metaquartzites. A detailed study of analogous sedimentary quartzites from Belgium was recently published by Veldeman et al. (2012). In hand specimen, tiny oval dark-green to oval-shaped black grains of glauconite can often be observed. Microscopically rare tourmaline, zircon and rutile grains are observed. The rock may locally contain silicified fossils, sponge spicules, and silicified plant root casts. Macroscopically, the quartzarenites develop characteristic undulating surfaces (socalled "mammelons"). Microscopically, rare feldspar, flint or chert grains may occur as well (Figure 8). In the literature these rocks are also referred to as Sarsen stones (West England), genetically they can be interpreted as groundwater silcretes (Dusar et al. 2009: 449-454; Dreesen \& Dusar 2011).

This rock type is of Thanetian and Lower Ypresian age and can be attributed to the Landen Group or the Formation of "Landen” (Late Paleocene-Early Eocene age). Deposits of this type of rock are known from the Pays de Bray (north of the Paris Basin, France) until Landen (province of Vlaams-Brabant, Belgium) passing by Binche (province of Hainaut, Belgium). Some outcrops are known from northwestern France (surroundings of Arras, Béthune and Valenciennes) and from Belgium in the province of Hainaut. Similar rocks, like the Tienen and Wommersom "quartzites" are reported from other Tertiary formations like the Formation of Tienen (Hesbaye area and province of Hainaut, Belgium). They are often referred to as mammillated sandstones ("grès mammelonés”) (Dusar et al. 2009; Dreesen \& Dusar 2011).

These quartzarenitic sandstones were already used in pre- and protohistory for the production of polishing and grinding tools (De Paepe \& Vermeulen 1988; Pirson et al. 2001). They were often extracted from isolated large surficial boulders, or so called "erratic sandstones" (grès erratiques, grès ladères): these boulders are the remaining silent witnesses of eroded sand deposits. Nevertheless, in more recent periods quarrying of the stone 'in situ' is also quite possible. No quarry sites are documented for the Roman period. Furthermore, these rocks were used as building stones and paving stones from the medieval period until the early $20^{\text {th }}$ century (Dusar et al. 2009). More research is required here to define the exact sources of the Tertiary quartzarenitic sandstones and to specify the various facies that were used during the Roman period. The presence of glauconite can be an indication for the marine facies of the Landen Group (the "Lower Landenian"), but this easily weathering mineral is often lacking, even within marine formations. Laga et al. (2001) recently described this unit as the Hannut Formation. 


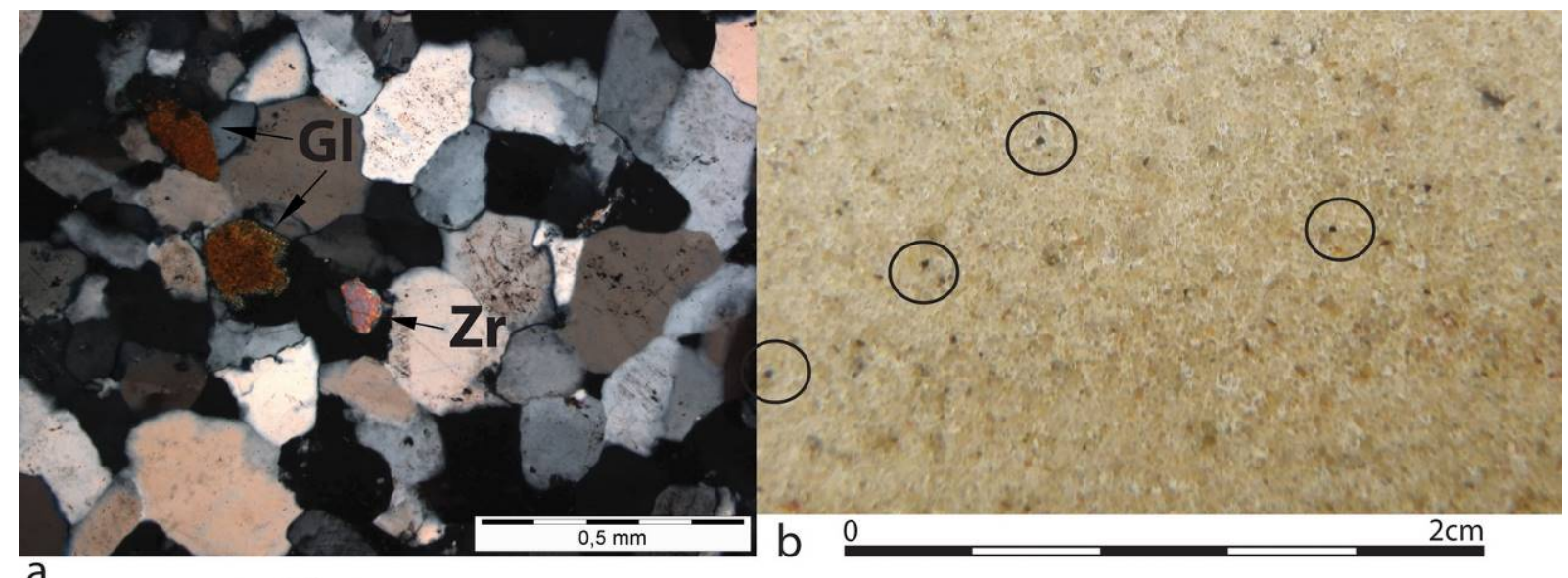

a

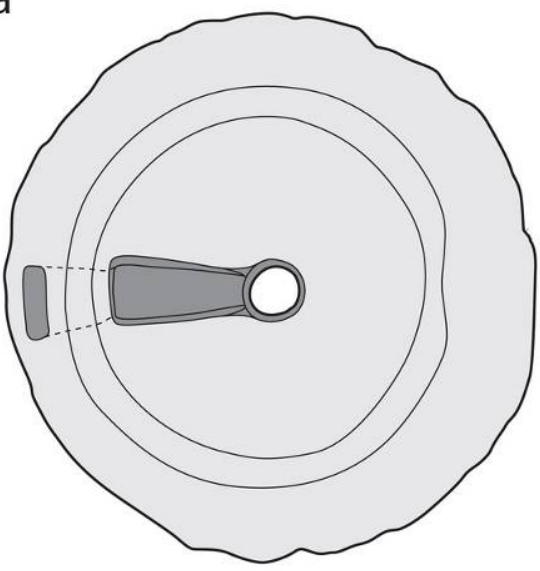

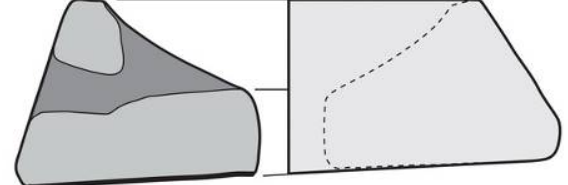

0

$20 \mathrm{~cm}$

C

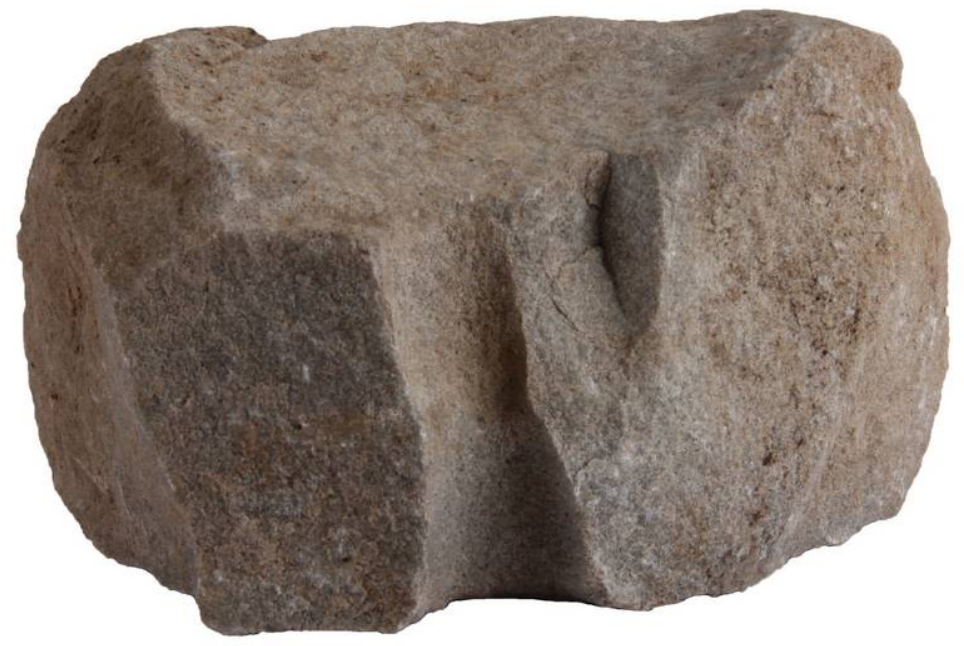

d 0

Figure 8. Tertiary quartzarenite. a) Micrograph of thin section: quartzarenite with rounded quartz grains in a quartzitic cement, two slightly weathered orange-brown glauconite (Gl) grains and one zircon (Zr) grain (accessory mineral). Transmitted light with cross polarization, b) Macroscopic detail: quartz grains cemented by silica and dark coloured oval-shaped glauconite grains. Some grains are highlighted by circles, c) Catillus from Carvin-France, d) Catillus from Uitbergen Wijmeers - Belgium.

For this type of rock only small querns (hand-mills) are known (Figure 8). They occur in the late Iron Age and some examples are known from (Early) Roman contexts. Their distribution was quite restricted. Examples are known from the French region of Nord-PasDe-Calais and to the Menapiorum and Tungrorum civitates.

\subsubsection{French Tertiary puddingstones}

Puddingstones are conglomeratic sedimentary rocks containing a large proportion of rounded flint pebbles in a matrix made of medium-grained quartz sand. Pebbles are black, grey, orange and reddish to beige and reach a width of 5 to $30 \mathrm{~mm}$.

The lithostratigraphic position of the puddingstone is not well defined. Outcrops are scattered in the Lower Seine valley (Department of Eure and Seine-Maritime, France), and occur in Tertiary residual flint formations superimposed on the cretaceous chalks of the Seine River basin. Pebbles result from the recycling of the underlying cretaceous flints during the 
Upper Thanetian and Ypresian (Upper Paleocene and Lower Eocene) and they are embedded in a siliceous sandy matrix (Figure 9).

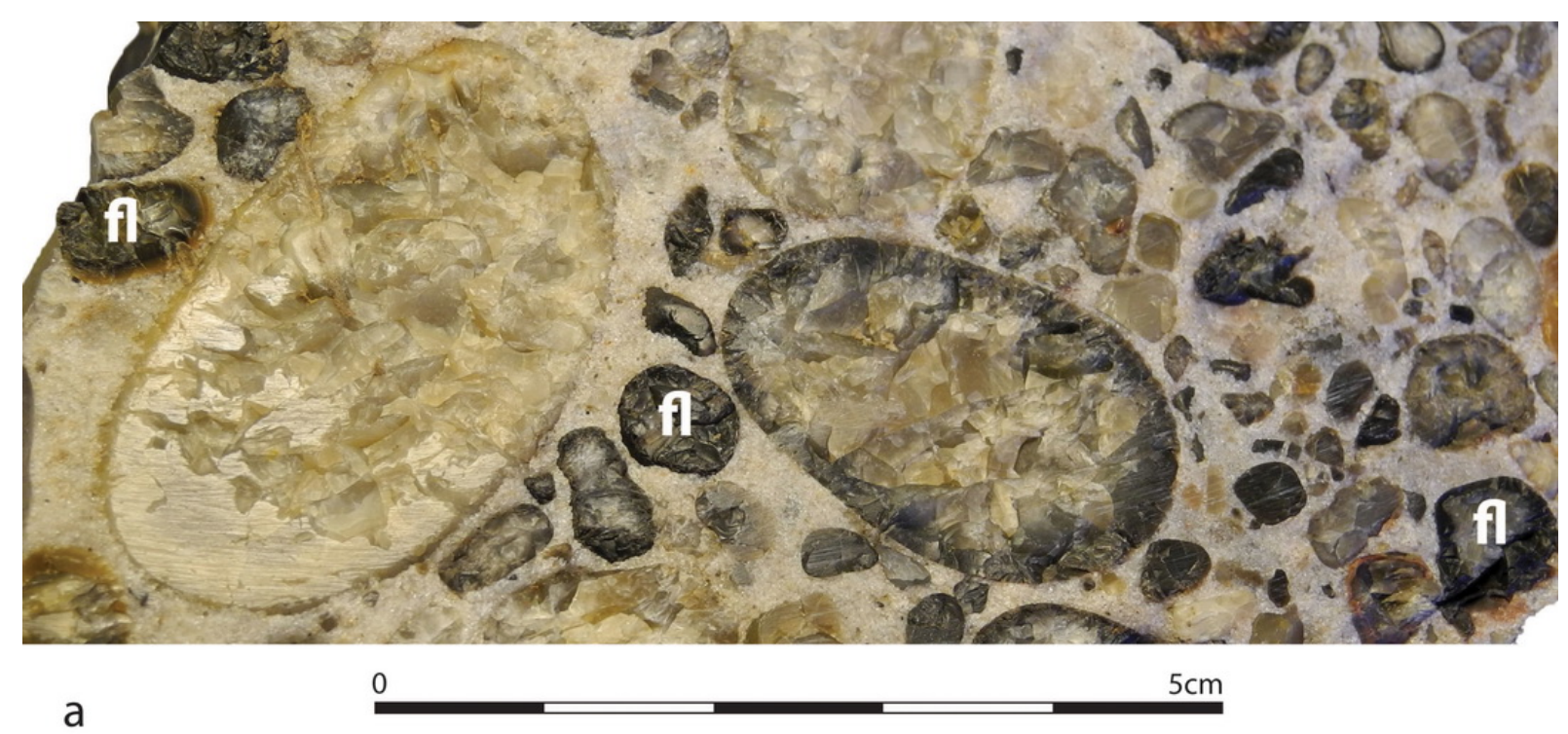

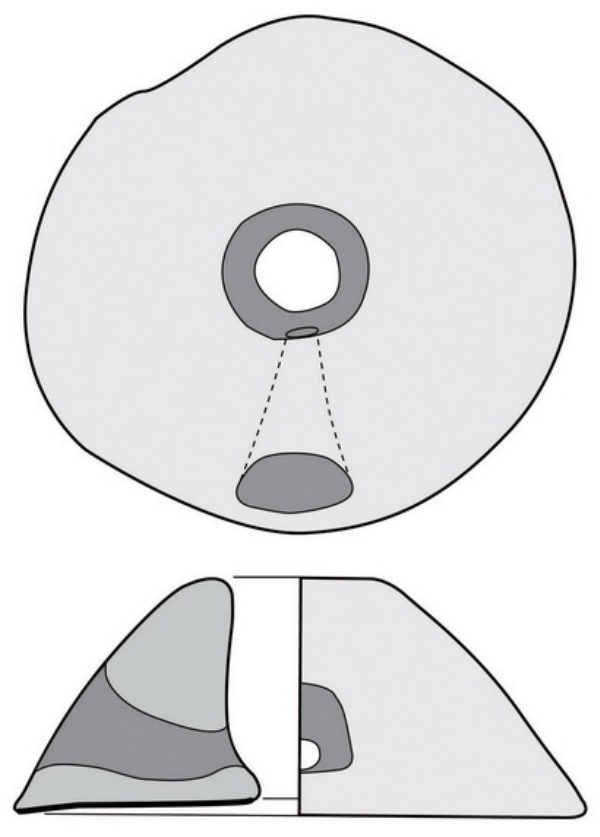

$0 \quad 20 \mathrm{~cm}$

b

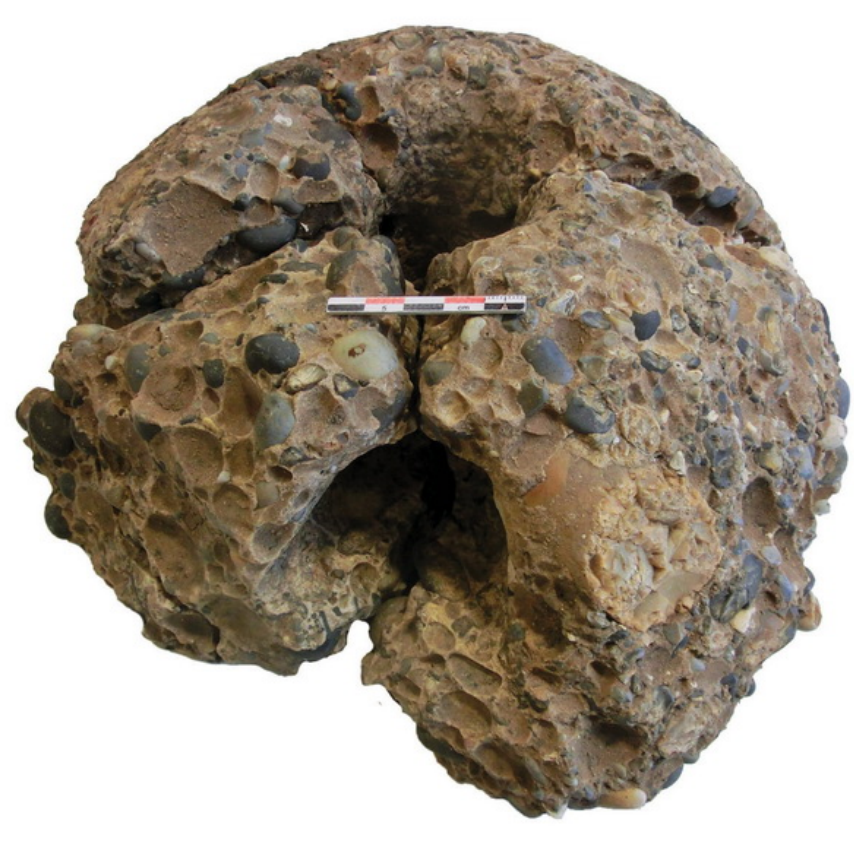

C

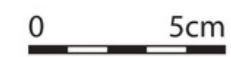

Figure 9. French Tertiary puddingstone. a) Macroscopic detail: rounded blackish flint (fl) and white quartz pebbles in a matrix of quartz sand, b) Catillus from Amiens-France, c) Catillus from Thérouanne.

Three potential extraction sites or quern workshops are known. They are all located in the Department of Seine-Maritime (Normandy, France): in Vaucottes (Saint-Léonard) near Fécamps, in the woods surrounding Saint-Saëns (south of the Forest of Eawy) and in the Forest of La Londe (Rémy-Watté 1983; Picavet 2011).

During protohistory, puddingstones were used around their primary outcrops for the production of saddle querns. From the end of the Iron Age and with the introduction of the 
first rotary querns they reach a wider distribution in northwestern France, even to some sites in the Aisne Valley in the east (Pommepuy 1999).

The querns of the same shape are distributed from the end of the Iron Age to the end of the Roman period. They are well represented along the Channel Coast of Normandy (RémyWatté 1983), Picardy, and Nord-Pas-de-Calais (Picavet 2011). Querns made in this rock don't occur in the Civitas Menapiorum or in the province of Limburg. A large number of these products are also found in southeast Britain, at least in Augustan levels (Green 2011; Green in press). The English equivalent on the other hand, the "Hertfordshire puddingstones", are unknown in northern Gaul.

\subsection{6. “Fosses-Belleu” Ypresian sandstones}

The "Fosses-Belleu" sandstones are grey to light-grey coloured quartzitic sandstones, consisting of medium-sized quartz grains within a siliceous matrix. Furthermore the rock contains rare but easily recognizable millimetric grains of black flint and white feldspars (Figure 10). An exhaustive study of this type of querns took place in 2014 in the framework of the conference of the research "Groupe Meule" organized in Reims (France) (LepareuxCouturier et al. in press).

The rock is of Ypresian (Basal Eocene) age and two localized outcrop areas of this formation are known in the central Paris Basin. These outcrops gave the rock its denomination: the first area is located around Fosses, Bellefontaine and Luzarches (Department of Val d'Oise, France) and the second around Belleu and Soissons (Department of Aisne, France). It seems that only the first one has been exploited during Antiquity for the production of hand-mills and to a lesser extent for larger water or animal driven mills. A small number of 'Pompeian' type millstones are known in Amiens, Reims and Meaux (Somme, Marne and Seine-et-Marne departments, France) (Jaccottey \& Longepierre 2011; Picavet 2011). In Bellefontaine, extraction activity is known while quern-shaping workshops are assumed on the banks of the Ysieux River Valley trough field survey (Boyer et al. 2010: 12-20). In the Belleu area, saddle querns were probably produced during protohistory (Pommepuy 1999), while there is currently no evidence of a Gallo-Roman production.

Querns made in the Fosses-Belleu sandstone are found in the entire Paris Basin as far south as north of the Seine (Lepareux-Couturier et al. in press). In Gallia Belgica, they occur within the same distribution network as the Lutetian glauconitic limestone (see further). Their distribution reaches the Somme River Basin and the city of Amiens (Department of Somme, France) but they are less abundant in Nord-Pas-de-Calais and even absent in Belgium.

\subsection{Lutetian limestones from northern Paris Basin}

In the northern part of the Paris Basin, specific calcareous levels have been used for quern production (Pommepuy 1999; Picavet 2011; Picavet in press b). These levels are situated in the various stratigraphical formations from the Lutetian (Eocene, Tertiary) in more or less deeply incised valleys (Aisne, Oise, Marne and Seine valleys). The area under consideration is very large and consists of the entire central Paris Basin. Some specific outcrops located in the northern part of the basin provided the northern bank of the Seine River during the Iron Age and Roman times. Each facies is easily distinguishable, nevertheless it has to be noted that a same facies can be found in numerous parts of the basin. In what follows we describe several types of Lutetian limestones that were used for quern and millstone production. 

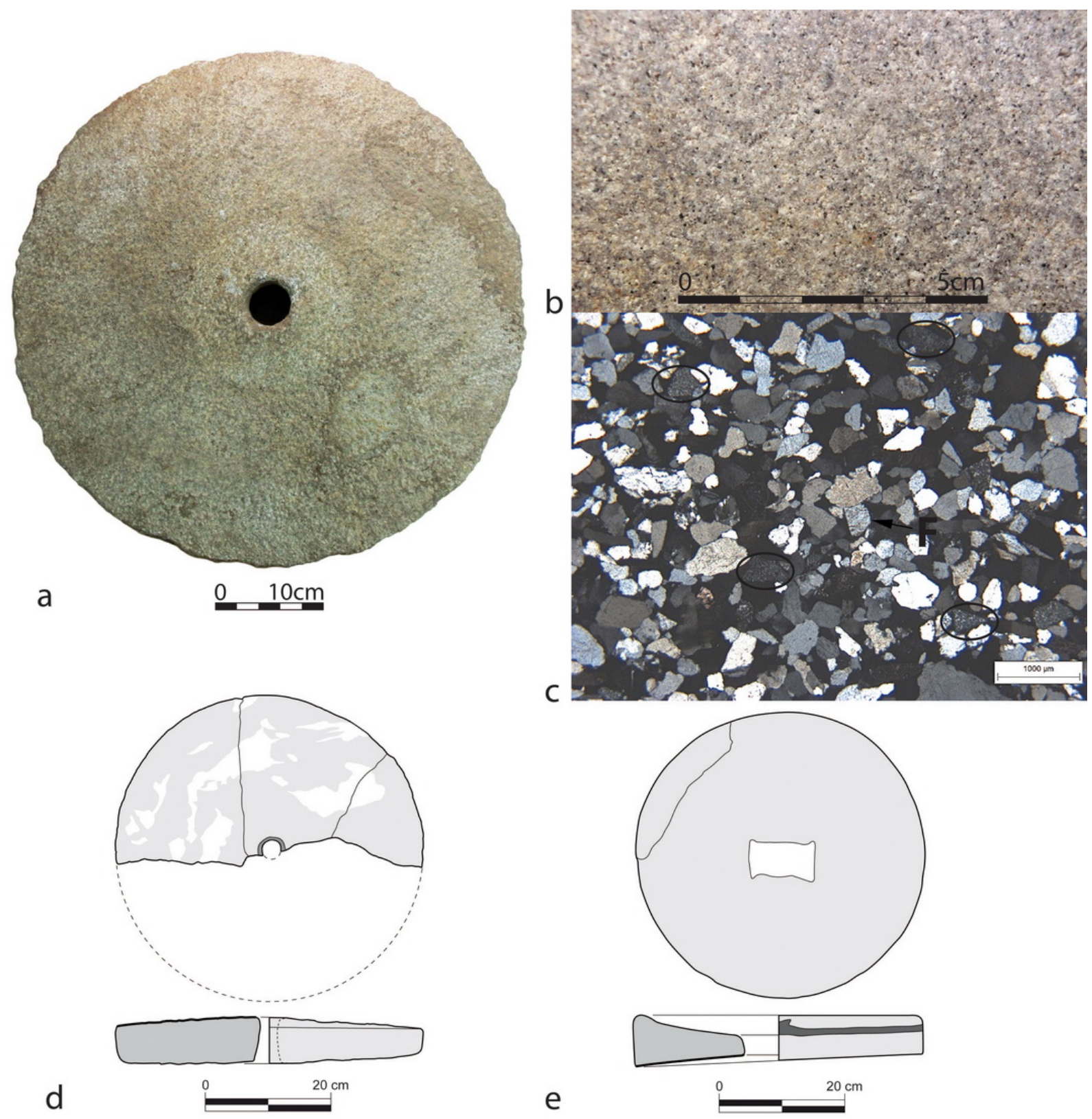

Figure 10. "Fosse-Belleu” Ypresian sandstone. a) Meta from Amiens-France, b) Macroscopic detail: quartz grains, grains of black flint and white feldspars, c) Micrograph of a thin section: quartzitic sandstone consisting of medium-sized quartz grains and flint grains (ellipses) within a siliceous matrix. Transmitted light with cross polarization, d) Meta from Nesle-France, e) Catillus from Amiens-France.

\subsection{1. "Vauxrezis” Lutetian glauconitic limestone}

Lower Lutetian (Eocene, Tertiary) limestones contain coarse detrital quartz grains, flint fragments and greenish glauconite grains. Numulites laevigatus, characteristic foraminifera, which looks like a little white centimetric saucer, is sparsely distributed (Figure 11).

An extraction workshop, exploited for the production of querns at least during the Late Iron Age, was identified in Vauxrezis next to Soissons (Aisne River valley, France) (Robert \& Landréat 2005). Although many Roman querns of this type of rock were found in Gallia Belgica, there are no known traces of Roman quarries in Vauxrezis.

These products, querns, and larger millstones, are predominant in Picardy during the Roman period together with the "Fosses-Belleu" sandstone (Picavet in press b). Further north it is still present but it competes with primary rocks from the Ardenne massif (Belgium and 
France) and with the "basalt"-like lava from the Eifel region (Germany). There are no examples of this type of rock known in the Civitas Menapiorium and in the province of Limburg.

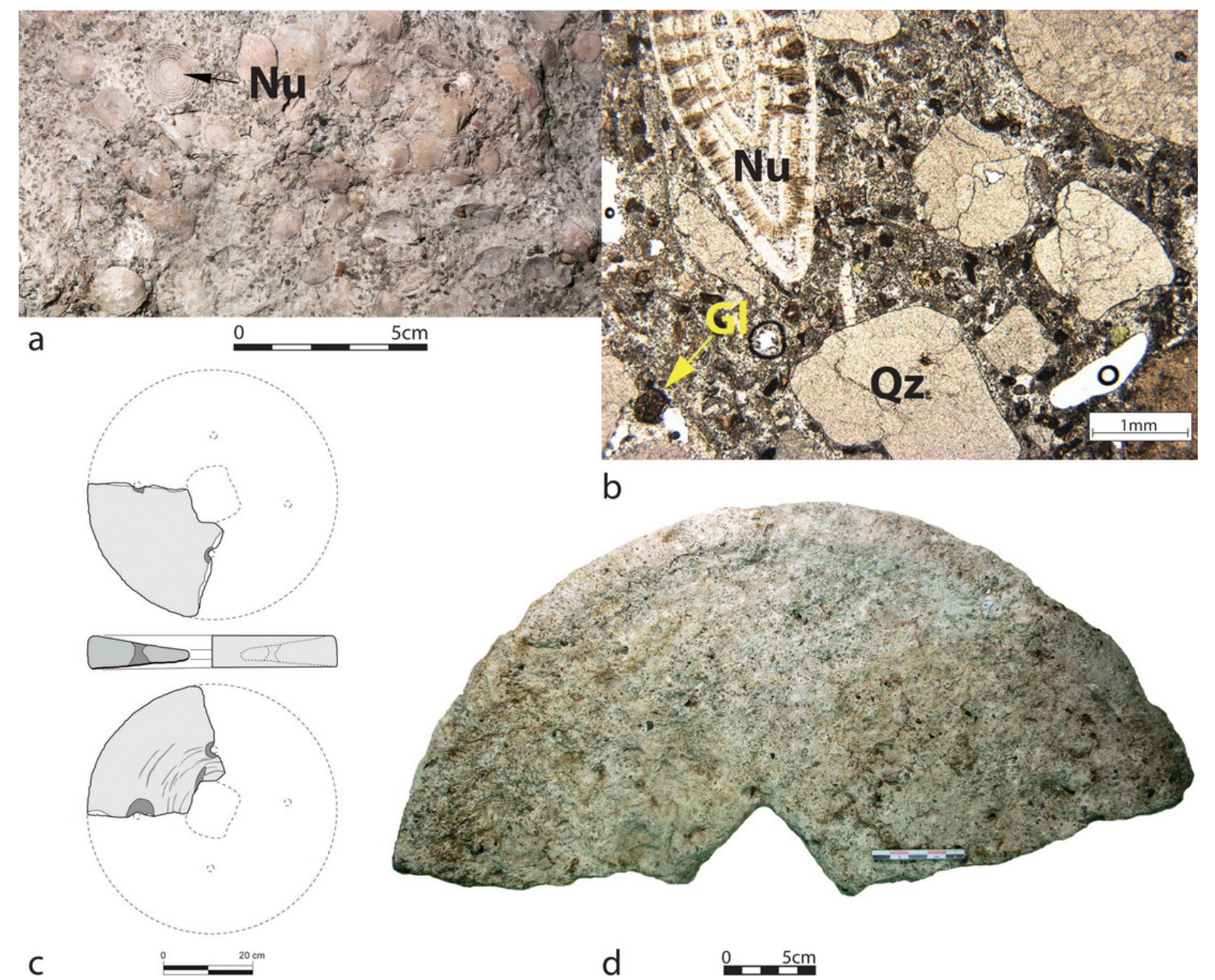

Figure 11. "Vauxrezis" Lutetian glauconite-rich limestone. a) Macroscopic detail: detrital quartz grains, glauconitic grains and in the left corner a characteristic foraminifer Nummulites laevigatus, b) Micrograph of thin section: sandy limestone, with partially recrystallized calcitic matrix, weathered glauconitic grains and Nummulites. Transmitted light without cross polarization, c) Catillus from Bethencourt-Sur-Somme - France, d) Catillus from Amiens-France.

\subsubsection{Lutetian limestone with shells of Cerithium}

This limestone from the Upper Lutetian is rich in fossils of Cerithium sp., gastropods that abound in Tertiary sedimentary deposits. These fossils are accompanied by Miliolidae, small foraminifera that are quite typical for these deposits (Fronteau et al. in press a) (Figure 12). Lutetian limestone with Cerithium can show grain-supported facies (packstone to grainstone) or matrix-supported wackestones. Outcrops are known from the Aisne and Oise river valleys (France). The discovery of unfinished querns enabled the localization of a quarry in Vendresse-Beaulne near Soissons (Department Aisne, France) (Naze et al. 2011). The Lutetian limestone with Cerithium is particularly preponderant during the Late Iron Age in the Aisne valley where it was used for some of the first rotary querns (most from the $1^{\text {st }}$ century B.C. (Pommepuy 1999). We keep seeing this rock to a lesser extent in Picardy through Roman times (Picavet in press $\mathrm{b}$ ). 

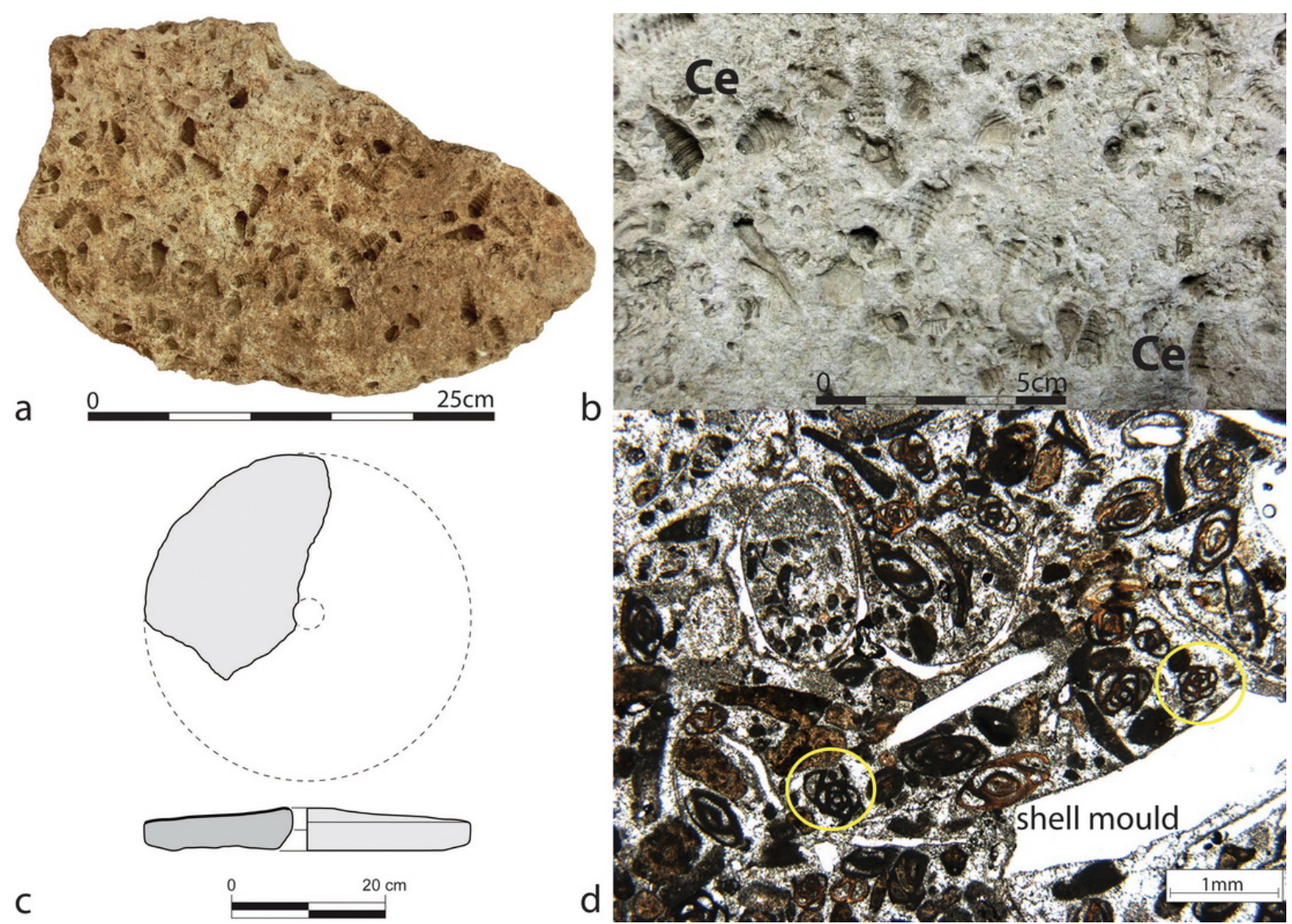

\section{C}
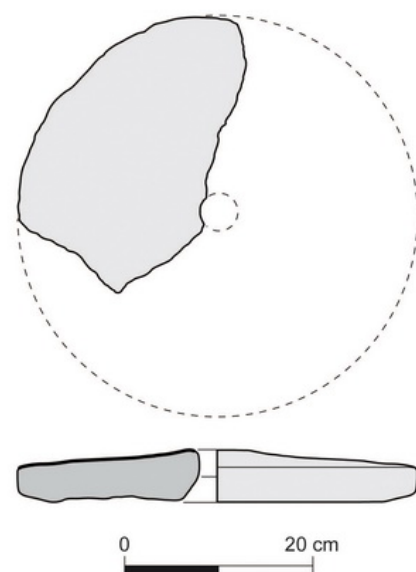

d

Figure 12. Lutetian limestone with shells of Cerithium (Ce). a) Meta from Bethencourt-Sur-Somme - France, b) Macroscopic detail: gastropod shell moulds, c) Meta from Bethencourt-Sur-Somme - France, d) Micrograph of thin section: bioclastic limestone, with calcitic spar cement, numerous miliolids (foraminifera - yellow circles) and gastropod shells moulds. Transmitted light without cross polarization.

\subsubsection{Other Lutetian limestones}

At least three additional types of Lutetian limestones were identified: they can all be differentiated by their fossil content. They have a limited distribution area and their exact geographic origin is still unknown. These rocks are well known in the Late Iron Age (Pommepuy 1999) but are more unusual during Antiquity.

- The limestone with Ditrupa strangulata, found on Roman settlements in and around Reims (Department Marne, France) (Picavet 2011; Fronteau et al. in press a). This yellow limestone contains calcified tubes produced by the worm Ditrupa strangulata, and was buried in calcareous mud of the Middle Lutetian (Eocene). Ditrupa limestones facies consist mainly of biomicrosparites and biosparites (packstones to grainstones). Querns made of this limestone are rare and neither quarries nor workshops are known.

- The "Pierre à liards" is a limestone essentially composed of numerous Nummulites laevigatus (large Foraminifera). It appears in the highest levels of the Lower Lutetian, on the banks of Aisne and Oise River Valleys (Picavet 2011). It is a coarse-grained, partially sandy limestone, which can also show a biosparitic facies with only few clastic elements. The querns made of this rock are found in Picardy (France) on Iron Age sites and are not yet known during the Antiquity.

- The Lymnaea-bearing limestone from the Upper Lutetian is abundant on the Iron Age settlement of Acy-Romance (eastern part of the Aisne valley) but absent in Roman contexts for millstones (Pommepuy 1999; Fronteau et al. in press b). Lymnea is a genus of small to large-sized air-breathing freshwater snails, aquatic pulmonate gastropod molluscs in the family Lymnaeidae. This limestone is a matrix-supported biomicrite (wackestone) facies. 


\section{Discussion and conclusions}

This article is the result of a fruitful collaboration between several geologists and archaeologists. It brought together the preliminary results of scholars working on provenance studies of querns and mills in the same macro-region, located at the northwestern border of the Roman Empire, permeating modern country borders. Two PhD studies are still in progress, whereas the study of querns and millstones of the Province of Limburg is finished and was recently published (Hartoch et al. 2015).

We showed that a large diversity of rock sources was exploited. From a geological and petrographical point of view, three major rock-groups could be distinguished: extrusive igneous rocks (volcanic rocks), detrital sedimentary rocks and limestones. The authors give evidence for the exploitation of at least seven different rock types that were used for the production of querns and millstones in the study region. Although we did not study the distribution and diversity of the productions in detail, we already presented some general patterns.

A very large exploitation area is located in the east, the volcanic Eifel field: the rocks derived from this area had a very large distribution in the study region (Gluhak \& Hofmeister 2011; Hartoch et al. 2015; Picavet in press b). Three other exploitation areas of detrital sedimentary rocks are located within the Ardenno-Rhenan Massif. They consist of dark red Devonian conglomerates, light-coloured Eodevonian coarse sandstones and conglomerates ('Macquenoise') and light-coloured Devonian arkosic coarse sandstones and conglomerates. The latter rock type had the largest distribution in the study region (Hartoch et al. 2015; Picavet in press b), whereas the other two exploitation areas were more restricted.

In the Paris Basin we distinguish two main exploitations: the exploitation of several types of Lutetian limestones and the exploitation of the Fosse-Belleu sandstone. The latter is located in the centre of the basin and its products were mainly distributed into the Paris and Somme basins (Lepareux-Couturier et al. in press). Occasionally the stone is found on archaeological sites in the departments Nord and Pas-de-Calais (France) whereas they are absent from to the northern areas (e.g. Belgian sites). In the north of the Paris Basin, different Lutetian limestones (at least five) were used to produce grinding tools. Most of them were used during the Late Iron Age, although some continued to be used during Antiquity like the Vauxrezis glauconitic limestone. The Lutetian limestones had a distribution throughout Picardy, in the Late Iron Age. Further to the north it was present during the Roman period but in competition with primary rocks from the Ardenne massif (Belgium and France) and with the "basalt"-like lava from the Eifel region (Germany) (Pommepuy 1999; Picavet in press b).

Examples from Belgian sites are absent at present. Finally, we mention two other exploitation areas: one in the lower Seine Valley and one extending from the south of the Flemish and North Sea Basin to the north of the Paris Basin. In the lower Seine Valley, a Tertiary puddingstone was distributed along the coast of Normandy, Picardy and Nord-Pasde-Calais (France) during the Roman period (Picavet 2011). The distribution of the Tertiary quartzarenites of which the potential source area is very large, was restricted to the northern part of the study region.

We showed that some exploitations had a very diverse production in terms of quern and millstone type, whereas others where more restricted. The productions of the "basalt"-like lavas from the Eifel, the Fosse-Belleu sandstone and to a lesser extent the Macquenoise sandstones were very diverse. Hand-mills as well as mechanical powered mills were produced in these rock types. The Fosse-Belleu sandstone was exploited to make hand-mills and to a lesser extent larger water and animal powered mills. Even some Pompeian-style millstones are known in this type of rock (Picavet 2011). For the Eifel area, the production of these hourglass-shaped millstones is also known (Gluhak \& Hofmeister 2011; Jaccottey \& 
Longepierre 2011; Hartoch et al. 2015: 32-44). Less diversity is noted in the production of arkosic sandstone, Tertiary puddingstone, Lutetian limestones and quartzarenitic sandstones. Whereas the arkosic sandstone is mainly linked with larger diameters (Hartoch et al. 2015: 240-248; Picavet in press a) the others produced only small hand-mills. The only exception is the Vauxrezis limestone in which larger mills are also known (Picavet 2011).

Clearly there is great potential in the study of these three different aspects (provenance, distribution patterns, diversity of the production). Further analysis of the data and comparison between micro-regions (studied within the context of the different research projects) will provide additional insights into the socio-economics of the local "Gallo-Roman" communities and into their networks within the northern Empire.

\section{Acknowledgments}

The authors would like to thank Dr. R. Shaffrey for proofreading this article. The authors are also grafteful to Drs. S. Vanhoutte and H. Denis (Agentschap Onroerend Erfgoed) for their permission to use the Oudenburg millstone photograph (Figure $4 \mathrm{~d}$ ).

\section{References}

Antonelli, F., Nappi, G., \& Lazzarini, L. 2001, Roman millstones from Orvieto (Italy): Petrographic and geochemical data for a new archaeometric contribution. Archaeometry, 43: 167-189. doi:10.1111/1475-4754.00013

Boulvain, F., \& Pingot, J.L. 2015, Génèse de sous-sol de la Wallonie (2 ${ }^{\text {ème }}$ édition revue et augmentée). Classe des Sciences. Académie royale de Belgique, Bruxelles, 208 p. (in French) ("The geology of the Walloon region ( $2{ }^{\text {nd }}$ edition review and augmented)")

Boyer, F., Cecchini, M., Garcia, C., \& Guadagnin, R. 2010, Étude archéologique du site de production meulière découverte dans la vallée de l'Ysieux (Val-d'Oise).Bulletin trimestriel d'Association Jeunesse Préhistorique et Géologique de France (Villiers-le$\mathrm{Bel}$ ), 1: 41 p. (in French) ("Archaeological study of the millstone production site in the Ysieux valley (Val-d’Oise)”)

Buchsenschutz, O., Jaccottey, L., Jodry, F., \& Blanchard, J. L. (Eds.) 2011, Evolution typologique et technique des meules du Néolithique à l'an mille. Actes des IIIe rencontres Archéologiques de l'Archéosite Gaulois, Rieux-Volvestre. Aquitania, Supplément Vol. 23, Editions de la Fédération Aquitania, Bordeaux, 480 p. (in French) ("Typological and technological evolution of millstones from the Neolithic until 1000 CE. Proceedings of the third archaeological assembly of «l'archéosite Gaulois»”)

Buffone, L., Lorenzoni, S., Pallara, M., \& Zanettin, E. 2003, The Millstones of ancient Pompeï: A petro-archaeometric study. European Journal of Mineralogy, 15 (1): $207-$ 2015. doi 10.1127/0935-1221/2003/0015-0207

Cattelain, L., Venant, N., Cosyns, P., Genvier S., Cattelain, P., Luppens, L., Picavet, P., \& Thiébaux A. 2013, La cave de la villa gallo-romaine de Neuville "Les Machenées" (Philippeville, province de Namur, Belgique) : Étude du matériel archéologique. Archéo-Situla, 32-33 (2012-2013): 19-68. (in French) ("The cellar of the Gallo Roman villa of Neuville "Les Machenées” (Philippeville, province of Namur, Belgium): A study of the archaeological material culture”)

Deru, X. 2010, Die Römer an Maas und Mosel. Verlag Philipp von Zabern, Mainz am Rhein, 136 p. (in German) ("Romans in Ancient Belgica”) 
Dreesen, R., Coquelet, C., Creemers, G., De Clercq, W., Fronteau, G., Gluhak, T. M., Hartoch, E., Henrich, P., Lafitte, J.-D., Picavet, P., Reniere, S., Ruppiene, V., Thiébaux, A., Vanderhoeven, A., Vynckier,G., \& Goemaere, E. 2014, Unraveling geological and geographical provenances of lithic materials during Roman times in Belgium: A fruitful collaboration between geologists and archaeologists. European Geologist, 38: 14-20.

Dreesen, R., \& Dusar, M. 2011, Duivelsstenen in Limburg: zwerfstenen, megalieten of getuigenstenen? Likona Jaarboek. Provinciaal natuurcentrum Limburg, 21: 14-29. (in Dutch) (“Devil stones in Limburg: boulders, megalites or witnesses stones?”)

Dusar, M., Dreesen, R., \& De Naeyer, A. 2009, Natuursteen in Vlaanderen, versteend verleden. Wolters Kluwer, Mechelen, 562 p. (in Dutch) ("Natural stone in Flanders, a petrified past”)

Folk, R.L. 1954, The distribution between grain size and mineral composition in sedimentary rock nomenclature. Journal of Geology, 62(4): 344-359.

URL: http://www.jstor.org/stable/30065016

Folk, R.L. 1974, The petrology of sedimentary rocks. Hemphill Publications, Austin, Texas, $182 \mathrm{p}$.

Fronteau, G., \& Boyer, F. 2011, Roches meulières: de la classification pétrographique à la classification texturale d'un potentiel "mécanique". In: Evolution typologique et technique des meules du Néolithique à l'an mille. Actes des IIIe rencontres Archéologiques de l'Archéosite Gaulois, Rieux-Volvestre, (Buchenschutz, O., Jaccottey, L., Jodry, F., \& Blanchard, J. L., Eds.), Aquitania, Supplément Vol. 23, Editions de la Fédération Aquitania, Bordeaux: p. 111-120. (in French) ("Millstone rocks: from petrographic classification to a textural classification of mecanical potential”)

Fronteau, G., Boyer,F., Frouin, M., Jaccottey, L., Lepareux-Couturier, S., Milleville, A., \& Picavet, $\mathrm{P}$. in press a, Les principales pierres meulières utilisées en ChampagneArdenne : Gisements, matériaux, utilisations. In: Les meules à grain du Néolithique à l'Époque Médiévale : technique, culture, diffusion, Reims, (Buchsenschutz, O., Fronteau, G. \& Lepareux-Couturier, S., Eds.), Revue Archéologique de l'Est, Supplément, CNRS Editions, Dijon: 18 p. (in French) ("The main used millstone rocks in Champagne-Ardenne: outrcops, material, use”)

Fronteau, G., Jaccottey, L., Jodry, F., \& Buchenschutz, O. in press b, Les outils de mouture du site d'Acy-Romance (Ardennes). In: Les meules à grain du Néolithique à l'Époque Médiévale: technique, culture, diffusion, Reims, (Buchsenschutz, O., Fronteau, G. \& Lepareux-Couturier, S., Eds.), Revue Archéologique de l’Est, Supplément, CNRS Editions, Dijon: 19 p. (in French) (“The milling tools of Acy Romance (Ardennes)”)

Gluhak, T. M. 2010, Petrologisch-geochemische Charakterisierung Quartärer Laven der Eifel als Grundlage zur Archäometrischen Herkunftsbestimmung Römischer Mühlsteine. Dissertation zur Erlangung des grades “Doktor der Naturwissenschaften” im promotionsfach Mineralogie, Johannes Gutenberg Universität, Mainz, 153 p. (in German) ("Petrographical-geochemical charachterization of Quarternary Lava from the Eifel as the basis for archaeometrical provenance studies of Roman millstones”)

Gluhak, T. M., \& Hofmeister, W. 2009, Roman lava quarries in the Eifel region (Germany): Geochemical data for millstone provenance studies. Journal of Archaeological Science, 36: 1774-1782. doi:10.1016./j.jas.2009.04.007 
Gluhak, T. M., \& Hofmeister, W. 2011, Geochemical provenance analyses of Roman lava millstones north of the Alps: a study of their distribution and implications for the beginning of Roman lava quarrying in the Eifel region (Germany). Journal of Archaeological Science, 38: 1603-1620. doi:10.1016/j.jas.2011.02.025

Green, C. 2011, Hertfordshire puddingstone querns: working a difficult rock. In: Bread for the People: The Archaeology of mills and milling. Proceedings of a colloquium held in the British School at Rome $4^{\text {th }}-7^{\text {th }}$ November 2009, (Williams, D., \& Peacock, D., Eds.), BAR International Series Vol. 2274, University of Southampton, Series in Archaeology Vol. 3, Archaeopress, Oxford: p.123-130.

Green, C. in press, Querns and millstones in Late Iron Age and Roman London and SouthEast England. In: Agriculture and Industry in South-Eastern Roman Britain (Bird, D. Ed.), Oxbow Books, Oxford, 15 p.

Hartoch, E., Doperé, F., Dreesen, R., Gluhak, T. M., Goemaere, E., Manteleers, I., Van Camp, L., \& Wefers, S. (Eds.), 2015, Moudre au Pays des Tungri, Atuatuca Vol. 7, Publications of the Gallo-Roman Museum of Tongeren, Tongeren, 416 p. (in French) ("Milling in the land of the Tungri")

Jaccottey, L., \& Longepierre, S. 2011, Les moulins de type Pompéi en France. In: Evolution typologique et technique des meules du Néolithique à l'an mille. Actes des IIIe rencontres Archéologiques de l'Archéosite Gaulois, Rieux-Volvestre (Buchenschutz, O., Jaccottey, L., Jodry, F., \& Blanchard, J. L., Eds.), Aquitania, Supplément Vol. 23, Editions de la Fédération Aquitania, Bordeaux: p. 85-116. (in French) ("Pompeian type of mills in France”)

Kars, H. 1980, Early-Medieval Dorestad, an archaeo-petrological study. Part I: general introduction. The tephrite querns. Berichten van de Rijksdienst voor het Oudheidkundige Bodemonderzoek, 30: 393-422.

Laga, P., Louweye, S., \& Geets, S. 2001, Paleogene and Neogene lithostratigraphic units (Belgium). Geologica Belgica, 4: 135-152. URL: http://popups.ulg.ac.be/13748505/index.php?id=1954

Lepareux-Couturier, S., Boyer, F., Fronteau, G., Hamon, C., Monchablon, C., Picavet, P., \& Robin, B. in press, Les Productions de meules en grès de Fosses-Belleu. TypologieChronologie-Diffusion. In: Les meules à grain du Néolithique à l'Époque Médiévale: technique, culture, diffusion, Reims, (Buchsenschutz, O., Fronteau, G. \& LepareuxCouturier, S., Eds.), Revue Archéologique de l'Est, Supplément, CNRS Editions, Dijon: 20 p. (in French) ("The millstone production in Fosses-Belleu sandstone”)

Mangartz, F. 2008, Römischer basaltlava-Abbau zwischen Eifel und Rhein, Monographien des Römisch-Germanisches Zentralmuseum. Band 7, Römisch-Germanisches Zentralmuseum, Mainz, 335 p. (in German) ("Roman basalt lava quarrying between Eifel and Rhine”)

Naze, Y., Fronteau, G., \& Robert, B. 2011, L’atelier de meules rotatives en calcaire à cérithes de Vendresse-Beaulne (Aisne). Note à propos des outils de mouture en calcaire Lutétien. In: Evolution typologique et technique des meules du Néolithique à l'an mille. Actes des IIIe rencontres Archéologiques de l'Archéosite Gaulois, Rieux-Volvestre, (Buchenschutz, O., Jaccottey, L., Jodry, F., \& Blanchard, J. L., Eds.), Aquitania, Supplément Vol. 23, Editions de la Fédération Aquitania, Bordeaux: p. 269-283. (in French) ("The workshop of rotary querns made of limestone with shells of Cerithium. Note about millings tools in Lutetian limestones”) 
De Paepe, P. 1965a, Onderzoek van enkele gesteenten afkomstig van de Gallo-Romeinse nederzetting te Huise. In: Oudheidkundige Opgravingen en Vondsten in OostVlaanderen, Vierde Reeks IV. Kultureel Jaarboek voor de Provincie Oost-Vlaanderen, Provinciebestuur Oost-Vlaanderen, Gent: p. 126-127. (in Dutch) ("Research of some stones from the Gallo Roman settlement of Huise”)

De Paepe, P. 1965b, Petrografisch onderzoek van enkele gesteenten afkomstig van de Romeinse nederzetting te Destelbergen (campagne 1965 en 1966). In: Oudheidkundige Opgravingen en Vondsten in Oost-Vlaanderen, Vierde Reeks. Kultureel Jaarboek voor de Provincie Oost-Vlaanderen, Provinciebestuur Oost-Vlaanderen, Gent: p. 160-164. (in Dutch) ("Petrographic research of some stones from the Roman settlement of Destelbergen”)

De Paepe, P. 1972, Beknopt overzicht van het gesteentemateriaal van de ijzertijdnederzetting te Huise-Lozer (kampagnes 1967 en 1969). In: Oudheidkundige Opgravingen en Vondsten in Oost-Vlaanderen, VI. Kultureel Jaarboek voor de Provincie OostVlaanderen. Bijdragen nieuwe reeks, Provinciebestuur Oost-Vlaanderen, Gent: p. 360361. (in Dutch) ("Concise overview of the stone finds from the Iron Age settlement of Huise-Lozer”)

De Paepe, P. 1976a, Gesteentemateriaal afkomstig van opgravingen op de plaats Tomberg in Beveren-Leie. De Leiegouw, 18: 397-400. (in Dutch) ("Stone finds from the excavations at the Tomberg in Beveren-Leie")

De Paepe, P. 1976b, Gesteentemateriaal van de opgravingen te Destelbergen 1967, 1969 en 1970. In: Oudheidkundige Opgravingen en Vondsten in Oost-Vlaanderen VII. Kultureel Jaarboek voor de Provincie Oost-Vlaanderen. Bijdragen nieuwe reeks, Provinciebestuur Oost-Vlaanderen, Gent: p. 71-72. (in Dutch) ("Stone finds from the excavations in Destelbergen 1967, 1969 and 1970”)

De Paepe, P., \& Vermeulen, F. 1988, Archeo-petrografisch onderzoek van natuursteen gevonden in enkele Gallo-Romeinse nederzettingen uit het Gentse. VOBOV-info, 32-33: 1-15. (in Dutch) ("Archaeological-petrographical research of stone finds found at some Gallo Roman settlements in the Ghent region”)

Peacock, D. 1980, Roman millstone trade: a petrological sketch. World Archaeology, 12: 4353. Stable URL: http://www.jstor.org/stable/124449

Pettijohn, E.J. 1975, Sedimentary rocks. Third Edition, Harper \& Row Publishers, New York, Evantson, San Francisco and London, 718 p.

Picavet, P. 2011, Les meules romaines de sept chefs-lieux de cité de Gaule Belgique occidentale, étude du matériel et synthèse bibliogaphique. Revue du Nord. Archéologie de la Picardie et du Nord de la France, 93: 167-226. (in French) ("The Roman mills from seven civitas capitals in the west of Gallia Belgica, material study and bibliographic synthesis”). doi:10.3917/rdn.393.0167

Picavet, $\mathrm{P}$. in press a, De grandes meules gallo-romaines à entrainement par le centre en grès découvertes dans le nord de la France et en Belgique. In : Actes du Colloque international de Lons-le-Saunier sur l'Archéologie des moulins hydrauliques, à traction animale et à vent, des origines à l'époque médiévale, 02-06 Novembre 2011 Lons-leSaunier, (Jacottey, L. \& Rollier, G., Eds.), Annales Université de Besançon, Besançon. p. 695-712. (in French) ("Large Gallo Roman sandstone mills driven from the centre found in Northern France and Belgium”) 
Picavet, P. in press b, Distribution des matériaux meuliers sur un transect Nord-Sud à travers la France septentrionale: les meules rotatives gauloises, gallo-romaines et altomédiévales du tracé du Canal Seine - Nord Europe (Inrap). In: Les meules à grain du Néolithique à l'Époque Médiévale: technique, culture, diffusion, Reims, (Buchsenschutz, O., Fronteau, G. \& Lepareux-Couturier, S., Eds.), Revue Archéologique de l’Est, Supplémént, CNRS Editions, Dijon: 12 p. (in French) ("Distribution of millstones raw materials on a North-South transect crossing Northern France: rotary querns from the Iron Age, Gallo Roman period and Early Medieval period found during the project of the channel Canal Seine - Nord Europe (Inrap)”)

Picavet, P., Boyer, F., Fronteau, G., \& Le Quellec, V. in press, Les productions de meules en grès dévonien dit « arkose » d'Haybes/Macquenoise de la fin de l'Âge du Fer à l'Antiquité tardive dans le nord de la Gaule. Caractérisation typologique, chronologie et diffusion. In: Les meules à grain du Néolithique à l'Époque Médiévale: technique, culture, diffusion, Reims, (Buchsenschutz, O., Fronteau, G. \& Lepareux-Couturier, S., Eds.), Revue Archéologique de l'Est, Supplémént, CNRS Editions, Dijon: 23 p. (in French) ("The millstone production in Devonian sandstone or "arkose" d'Haybes/Macquenoise from the Late Iron age until the Late Antiquity in Northern Gaul. Typological characterization, chronology and distribution”)

Pirson, S., Dupuis, C., Baele, J. M., Collet, H., \& Mortier, T. 2001, Fragments de polissoirs découvertes à Petit-Spiennes: pétrographie et implications archéologiques. Notae Praehistoricae, 21: 145-156. (in French) ("Fragments of polishing tools found at PetitSpiennes : petrography and archaeological implications”).

URL: http://www.naturalsciences.be/mars/groups/fnrs-contact-group/notaepraehistoricae/notae-praehistoricae-21-2001

Pommepuy, C. 1999, Le matériel de mouture de la valée de l'Aisne de l'âge du bronze à La Tène finale: formes et matériaux. Revue archéologique de Picardie,3(1): 115-141. (in French) ("Milling tools from the Aisne valley from the Bronze Age until the Late Iron Age (La Tène finale): typology and raw materials”). doi:10.3406/pica.1999.2217

Rémy-Watté, M. 1983, Meules à grains tournantes antiques en Seine-Maritime. Bulletin de la Société Normande d'Etudes Préhistoriques et Historique, 46: 18-47. (in French) (“Antique rotary grain mills from Seine-Maritime”)

Reniere, S., De Clercq, W., Dreesen, R., Cnudde, V., De Kock, T. \& Goemaere, E. in press, A la recherche des meules romaines dans un paysage dépourvu de ressources lithiques. Premier bilan d'une analyse multidisciplinaire dans le Civitas Menapiorum (Belgique). In: Les meules à grain du Néolithique à l'Époque Médiévale: technique, culture, diffusion, Reims, (Buchsenschutz, O., Fronteau, G. \& Lepareux-Couturier, S., Eds.), Revue Archéologique de l’Est, Supplémént, CNRS Editions, Dijon: 7 p. (in French) ("Searching for Roman mills in a stoneless landscape. First results on a multidisciplinary analysis in the Civitas Menapiorum (Belgium)”)

Renzulli, A., Santi, P., Nappi, G., Luni, M. \& Vitali, D. 2002, Provenance and trade of volcanic rock millstones from Etruscan-Celtic and Roman archaeological sites in Central Italy. European Journal of mineralogy, 14 (1): 175-183. doi:10.1127/09351221/2002/0014-0175 
Robert, B. \& Landréat, J.-L. 2005, Les meules rotatives en calcaire à glauconie grossière et l'atelier de Vauxrezis (Aisne). Un état de la question. In: Hommage à Claudine Pommepuy (Auxiette, G. \& Malrain, F., Eds.), Revue Archéologique de Picardie, Numéro Spécial Vol. 22, Amiens: p. 105-114. (in French) ("Rotary querns made from a limestone with coarse glauconite and the workshop of Vauxrezis (Aisne). State of research”). doi:10.3406/pica.2005.2723

Stainier, P. 1994, Formation de Burnot. In: Les formations de Dévonien inférieur du Massif de la Vesdre, de la Fenêtre de Theux et du Synclinorium de Dinant (Belgique, France), (Godefroid, J., Blieck, A., Bultynck, P., Dejonghe, L., Gerrienne, P., Hance, L., Meilliez, F., Stainier, P. \& Steemans, P., Eds.), Mémoires Pour Servir à l’Explication des Cartes Géologiques et Minières de la Belgique Vol. 38, Geological Survey Of Belgium, Bruxelles: p. 133-138. (in French) (Burnot Formation in: Lower Devonian geological formations from the Vesdre Massif, the Theux Window and the Dinant Synclinorium (Belgium, France))

Veldeman, I., Baele, J.M., Goemaere, E., De Ceukelaire, M., Dusar, M. \& De Doncker, H.W.J.A. 2012, Characterizing the hypersilicious rocks of Belgium used in (pre-)history: A case study on sourcing sedimentary quartzites. Journal of Geophysics and Engineering, 9: 118-128. doi:10.1088/1742-2132/9/4/S118

Williams-Thorpe, O., \& Thorpe, R.S. 1993, Geochemistry and trade of Eastern Mediterranean millstones from the Neolithic to Roman periods. Journal of Archaeological Science, 20: 263-320. doi:10.1006/jasc.1993.1018 